\title{
Development of Ni-Based Catalysts for Steam Reforming of Tar Derived from Biomass Pyrolysis
}

\author{
Dalin LI ${ }^{1,2}$, Yoshinao NAKAGAWA ${ }^{1}$, Keiichi TOMISHIGE ${ }^{1, *}$ \\ ${ }^{1}$ Department of Applied Chemistry, School of Engineering, Tohoku University, Sendai 980-8579, Japan \\ ${ }^{2}$ National Engineering Research Center of Chemical Fertilizer Catalyst, Fuzhou University, Fuzhou 350002, Fujian, China
}

\begin{abstract}
Nickel catalysts are effective for the steam reforming of tar derived from biomass pyrolysis, but the improvement is needed in terms of activity, stability, suppression of coke deposition and aggregation, and regeneration. Our recent development of Ni-based catalysts for the steam reforming of tar is reviewed including the modification with $\mathrm{CeO}_{2}$ (or $\mathrm{MnO}$ ), trace $\mathrm{Pt}$, and $\mathrm{MgO}$. The role of additives such as $\mathrm{CeO}_{2}, \mathrm{MnO}, \mathrm{Pt}$, and $\mathrm{MgO}$ is also discussed.
\end{abstract}

Key words: steam reforming; tar; biomass; nickel; ceria; manganese oxide; platinum; magnesia CLC number: O643 Document code: A

Received 30 October 2011. Accepted 14 December 2011.

*Corresponding author.Tel: +81-22-795-7214; Fax: +81-22-795-7214; E-mail: tomi@erec.che.tohoku.ac.jp

This work was supported by Japan Science and Technology Agency (JST), Ministry of Education, Culture, Sports, Science and Technology, Japan.

English edition available online at Elsevier ScienceDirect (http://www.sciencedirect.com/science/journal/18722067).

Conversion of biomass to synthesis gas and hydrogen is one of the important technologies for the energy utilization of biomass by the power generation and the production of liquid fuels by Fischer-Tropsch synthesis and chemicals by methanol synthesis [1-4]. The gasification of biomass to synthesis gas and hydrogen has been conventionally carried out in a non-catalytic system at very high temperature (> $1073 \mathrm{~K}$ ) in order to decrease the concentration of the residual tar [4]. In the non-catalytic gasification, air is usually used as a gasifying agent. Therefore, the product gas is diluted with nitrogen and this makes the product gas unsuitable to the chemical conversion. Another gasification method is the catalytic steam reforming of tar derived from the pyrolysis of biomass at much lower temperature than the case of non-catalytic gasification with air. It has been known that rapid pyrolysis at low temperature such as 773 $\mathrm{K}$ gives high yield of the mixture of volatile organic compounds, which is called as tar or bio-oil. When steam reforming reaction of the tar can proceed at low temperature comparable to the case of the pyrolysis, the combination of the rapid pyrolysis and catalytic steam reforming will enable the low-temperature gasification of biomass to synthesis gas and hydrogen.

In the steam reforming of tar, catalysts with high performance in terms of the activity and stability are needed. Moreover, it is considered that high abilities in the catalyst activation and the catalyst regeneration are important properties in the process for the biomass conversion to synthesis gas and hydrogen. If the catalysts can be activated automatically by the introduction of the biomass tar at the reaction temperature, this self-activation property can contribute to the easier operation of the process. On the other hand, the coke deposited on the catalysts can be reduced to some extent, but the complete suppression is difficult. The coke removal such as by the combustion is necessary. However, the procedure for the coke removal can cause the catalyst deactivation by the sintering of a support material and the aggregation of metal particles. If the catalysts are recyclable by the re-dispersion of the aggregated particles, the catalyst cost can be decreased. The self-activation and self-regeneration properties as well as high steam reforming activity and the suppression of coke formation can contribute to the development of more feasible process. Applicability of the commercial and conventional steam reforming catalysts has been evaluated [5-10]. However, in fact, the performance of the conventional catalysts is not satisfactory, and the development of the catalysts for the steam reforming of tar derived from the biomass pyrolysis is highly needed.

Table 1 lists the examples of recent reports on Ni catalysts for the tar conversion in the gasification of real biomass. A nano- $\mathrm{NiO} / \gamma-\mathrm{Al}_{2} \mathrm{O}_{3}$ catalyst was reported by $\mathrm{Li}$ et al. [11] to show high activity in cracking of tar and hydrocarbons. Another nano-Ni-La-Fe/ $/ \mathrm{Al}_{2} \mathrm{O}_{3}$ catalyst was also developed by $\mathrm{Li}$ et al. [12]. In the presence of the catalyst, the tar remove efficiency reached $99 \%$ at $1073 \mathrm{~K}$, and the coke deposition and sintering effects were avoided, leading to a 
Table 1 Recent reports on Ni catalysts for biomass gasification

\begin{tabular}{|c|c|c|c|c|c|}
\hline Biomass & Catalyst & $\begin{array}{c}\text { Ni content } \\
(w t \%)\end{array}$ & $\begin{array}{c}\text { Catalyst } \\
\text { amount (g) }\end{array}$ & $\begin{array}{c}\text { Reactor } \\
(\text { diameter } \times \text { height }, \mathrm{mm})\end{array}$ & Ref. \\
\hline Rice husk & $\mathrm{NiO} / \gamma-\mathrm{Al}_{2} \mathrm{O}_{3}$ & 12 & 1000 & fixed-bed $(88 \times 1200)$ & {$[11]$} \\
\hline Sawdust & $\mathrm{NiO} / \gamma-\mathrm{Al}_{2} \mathrm{O}_{3}$ & 12 & 1000 & fixed-bed $(88 \times 1200)$ & [12] \\
\hline Sawdust & $\mathrm{Ni}-\mathrm{La}-\mathrm{Fe} / \gamma-\mathrm{Al}_{2} \mathrm{O}_{3}$ & 8.6 & 1000 & fixed-bed $(88 \times 1200)$ & {$[12]$} \\
\hline Pine sawdust & $\mathrm{NiO}-\mathrm{MgO}$ & 19.5 & 20 & fluidized-bed $(20 \times 800)$ & {$[13]$} \\
\hline Pine sawdust & $\mathrm{Ni} / \mathrm{MgO}$ & 19.5 & 20 & fluidized-bed $(20 \times 800)$ & [13] \\
\hline Pine sawdust & $\mathrm{Ni}_{0.03} \mathrm{Mg}_{0.97} \mathrm{O}$ & 4.3 & 20 & fluidized-bed $(20 \times 800)$ & {$[13]$} \\
\hline Red pine & $\mathrm{Ni} / \mathrm{Al}_{2} \mathrm{O}_{3}$ & 20 & 45 & fixed-bed $(53.5 \times 610)$ & {$[14]$} \\
\hline Red pine & $\mathrm{Ni} / \mathrm{Al}_{2} \mathrm{O}_{3}$ & 20 & 100 & fixed-bed $(53.5 \times 610)$ & {$[15]$} \\
\hline Red pine & $\mathrm{Ni} /$ coal char & 9 & 100 & fixed-bed $(53.5 \times 610)$ & {$[14,15]$} \\
\hline Sawdust & $\mathrm{Ni} /$ wood char & $5-20$ & 18 & fixed-bed $(25 \times 610)$ & {$[16]$} \\
\hline Sawdust & $\mathrm{Ni} /$ coal char & $5-20$ & 18 & fixed-bed $(25 \times 610)$ & {$[16]$} \\
\hline Eucalyptus twig sawdust & $\mathrm{NiO} /$ dolomite & $0.4-4.3$ & 2 & fixed-bed $(22 \times 700)$ & {$[17]$} \\
\hline Cedar & $\mathrm{Ni} /$ oxide (oxide: $\mathrm{Al}_{2} \mathrm{O}_{3}, \mathrm{ZrO}_{2}, \mathrm{TiO}_{2}, \mathrm{CeO}_{2}, \mathrm{MgO}$ ) & 12 & 1 & fixed-bed $(10 \times 290)$ & {$[26]$} \\
\hline Cedar & $\mathrm{Ni} / \mathrm{CeO}_{2} / \mathrm{Al}_{2} \mathrm{O}_{3}$ & 4,12 & 1 & fixed-bed $(10 \times 290)$ & {$[27,28]$} \\
\hline Cedar & $\mathrm{M}-\mathrm{Ni} / \mathrm{CeO}_{2} / \mathrm{Al}_{2} \mathrm{O}_{3}(\mathrm{M}=\mathrm{Pt}, \mathrm{Pd}, \mathrm{Rh}, \mathrm{Ru})$ & 4,12 & 1 & fixed-bed $(10 \times 290)$ & {$[29,30]$} \\
\hline Cedar & $\mathrm{Pt} / \mathrm{Ni} / \mathrm{CeO}_{2} / \mathrm{MgO} / \mathrm{Al}_{2} \mathrm{O}_{3}$ & 12 & 1 & fixed-bed $(10 \times 290)$ & {$[31]$} \\
\hline Cedar & $\mathrm{Ni} / \mathrm{MnO} / \mathrm{Al}_{2} \mathrm{O}_{3}$ & 12 & 1 & fixed-bed $(10 \times 290)$ & {$[32]$} \\
\hline
\end{tabular}

long lifetime of catalysts. Wang et al. [13] reported a $\mathrm{NiO}-\mathrm{MgO}$ catalyst exhibiting high stable activity for the reforming of raw fuel gas from gasifier. The highly stable activity was attributed to the high dispersion of Ni particles in the NiO-MgO solid solution structure and the promotion by catalyst reducibility. Recently, Le et al. [14] developed a Ni-loaded brown coal char for the steam reforming of tar. Compared to conventional $\mathrm{Ni} / \mathrm{Al}_{2} \mathrm{O}_{3}$, Ni-loaded brown coal char has a higher activity and stability with coke resistance [15]. It was also reported by Wang et al. [16] that coal char supported $\mathrm{Ni}$ and wool char supported Ni catalysts are effective for tar removal, converting more than $97 \%$ of tars in synthesis gas at $1073 \mathrm{~K}$. Corujo et al. [17] reported that the use of NiO-loaded calcined dolomite catalysts led to a reduction in the formation rate of tar and char and a $30 \%$ increase in the total product gas. As listed in Table 1, the amount of catalysts was rather large in most cases. This large amount of catalysts needed for the activity tests makes it difficult to optimize the catalyst composition, the preparation method, pre-treatment conditions, and so on. In fact, the number of the tested catalysts in most cases is so limited. On the other hand, in our case, the reactor size is rather small, and only $1 \mathrm{~g}$ catalyst is needed, then various catalysts can be easily tested and this enables the development of the catalysts tuned for the catalytic gasification of biomass [18-25] and the steam reforming of the biomass tar [26-34].

On the other hand, addition of secondary metal or metal oxide is a promising approach for tuning or design new catalysts. In this approach, the optimum amount of the additives is usually present. For example, in the case of metal catalysts modified with oxides and secondary metals, the interface between metal and the modifier can be a catalyti- cally active site, and the amount of the interface has a maximum with respect to the additive amount of the modifier, such as $\mathrm{Rh}-\mathrm{M} / \mathrm{MgO}(\mathrm{M}=\mathrm{Co}, \mathrm{Ni}, \mathrm{Fe})$ catalysts for the catalytic partial oxidation of methane [35-37], Rh- $\mathrm{MO}_{x}(\mathrm{M}$ $=\mathrm{Mo}, \mathrm{Re})$ catalysts for the hydrogenolysis of biomass-derived polyols and cyclic ethers [38-42], Pt-ReO catalysts for the preferential $\mathrm{CO}$ oxidation in a $\mathrm{H}_{2}$-rich stream $[43,44]$, and so on. It has been known that $\mathrm{Ni}$ is one of the suitable components for the steam reforming of various organic compounds, and the effects of supports and additive oxides and other metals have been investigated. Our group has reported that the addition of $\mathrm{CeO}_{2}[27,28]$ and $\mathrm{MnO}$ [32] to $\mathrm{Ni}$ catalysts enhanced the catalytic performance in terms of the activity and the suppression of coke formation in the steam reforming of the biomass tar. In particular, the suppression of coke formation is related to the catalyst stability. We also attempted to attach the self-activation and self-regeneration properties to $\mathrm{Ni} / \mathrm{CeO}_{2} /$ $\mathrm{Al}_{2} \mathrm{O}_{3}$ catalysts by modification with a small amount of $\mathrm{Pt}$ and $\mathrm{MgO}$ [29-31].

This review article shows the development process of $\mathrm{Ni} / \mathrm{Al}_{2} \mathrm{O}_{3}$ modified with $\mathrm{CeO}_{2}, \mathrm{Pt}$, and $\mathrm{MgO}$ in order to make the multi-functional catalyst for the steam reforming of tar derived from the wood pyrolysis.

\section{Steam reforming of tar over Ni catalysts supported on different oxides [26]}

$\mathrm{Ni}$ catalysts supported on various oxides, i.e., $\mathrm{Ni} / \mathrm{Al}_{2} \mathrm{O}_{3}$, $\mathrm{Ni} / \mathrm{ZrO}_{2}, \mathrm{Ni} / \mathrm{TiO}_{2}, \mathrm{Ni} / \mathrm{CeO}_{2}$, and $\mathrm{Ni} / \mathrm{MgO}$ were prepared by the incipient wetness method using an aqueous solution of $\mathrm{Ni}\left(\mathrm{NO}_{3}\right)_{2} \cdot 6 \mathrm{H}_{2} \mathrm{O}$. The method for the preparation of the sup- 
port materials were described in our previous report [26]. The calcination conditions for the preparation of the supports are listed in Table 2. It should be noted that all the alumina supports in this review were $\alpha-\mathrm{Al}_{2} \mathrm{O}_{3}$. After impregnation, the sample was dried at $383 \mathrm{~K}$ for $12 \mathrm{~h}$ followed by calcination at $773 \mathrm{~K}$ for $3 \mathrm{~h}$ under air atmosphere. The loading amount of $\mathrm{Ni}$ is described in parentheses as mass percent on all the catalysts. Cedar wood was used as the biomass feedstock for all experiments. Steam reforming of tar was carried out in a laboratory-scale continuous feeding dual-bed reactor [26]. In this system, tar is formed by the rapid pyrolysis of cedar wood in the presence of steam, and it is introduced to the secondary catalyst bed together with steam. Before catalytic reaction, the catalyst was pre-reduced in $\mathrm{H}_{2}$ at $773 \mathrm{~K}$ for $0.5 \mathrm{~h}$.

Table 2 Properties of Ni catalysts supported on different oxides [26]

\begin{tabular}{|c|c|c|c|c|c|c|c|c|}
\hline \multirow{2}{*}{ Catalyst } & \multicolumn{2}{|c|}{ Calcination conditions } & \multirow{2}{*}{$\begin{array}{c}\text { BET surface area } \\
\left(\mathrm{m}^{2} / \mathrm{g}_{\text {cat }}\right)\end{array}$} & \multirow{2}{*}{$\begin{array}{l}\mathrm{H}_{2} \text { adsorption }^{\mathrm{b}} \\
\left(10^{-6} \mathrm{~mol} / \mathrm{g}_{\text {cat }}\right)\end{array}$} & \multirow{2}{*}{$\begin{array}{l}\text { Reduction degree } \\
\text { from } \operatorname{TPR}^{\mathrm{c}}(\%)\end{array}$} & \multirow{2}{*}{$\begin{array}{c}\text { Dispersion }^{\mathrm{d}} \\
(\%)\end{array}$} & \multicolumn{2}{|c|}{ Particle size of Ni metal $(\mathrm{nm})$} \\
\hline & Temperature $(\mathrm{K})$ & Time (h) & & & & & $\mathrm{H}_{2}$ adsorption $^{\mathrm{e}}$ & $\mathrm{XRD}^{\mathrm{f}}$ \\
\hline $\mathrm{Ni}(12) / \mathrm{Al}_{2} \mathrm{O}_{3}$ & 1423 & 1 & 8 & 27 & 106 & 2.7 & 36 & 31 \\
\hline $\mathrm{Ni}(12) / \mathrm{ZrO}_{2}$ & 1073 & 3 & 10 & 30 & 96 & 3.0 & 31 & 29 \\
\hline $\mathrm{Ni}(12) / \mathrm{TiO}_{2}$ & 1173 & 3 & 16 & 28 & 97 & 2.8 & 34 & 21 \\
\hline $\mathrm{Ni}(12) / \mathrm{CeO}_{2}$ & 1073 & 3 & 12 & 17 & 106 & 1.7 & 56 & 58 \\
\hline $\mathrm{Ni}(12) / \mathrm{MgO}$ & $-^{\mathrm{a}}$ & - & 12 & 3 & 20 & 1.5 & 64 & n.d. \\
\hline
\end{tabular}

${ }^{\mathrm{a}} \mathrm{MgO}$ support was used without precalcination.

${ }^{\mathrm{b}} \mathrm{H}_{2}$ adsorption is total adsorption at room temperature, and $\mathrm{H} / \mathrm{Ni}=1$ is assumed.

${ }^{\mathrm{c} C}$ Calculated by $\left(\mathrm{H}_{2}\right.$ consumption in TPR profiles)/(loading amount of $\left.\mathrm{Ni}\right) \times 100 \%$, assuming that $\mathrm{Ni}^{2+}+\mathrm{H}_{2} \rightarrow \mathrm{Ni}^{0}+2 \mathrm{H}^{+}$.

${ }^{\mathrm{d}}$ Dispersion calculated by $2 \times\left(\mathrm{H}_{2}\right.$ adsorption $) /($ loading amount of $\mathrm{Ni}) /($ reduction degree $) \times 100 \%[45,46]$.

${ }^{\mathrm{e}}$ Particle size of Ni metal calculated by the relation: $($ particle size $/ \mathrm{nm})=9.71 /($ dispersion/\%) $\times 10[45,46]$.

${ }^{\mathrm{f}}$ Particle size of Ni metal calculated from the Scherrer equation, using the full width at half height of the strong intensity metal peak.

Table 3 summarizes the results of various supported $\mathrm{Ni}$ catalysts in steam reforming of tar at $823 \mathrm{~K}$ together with that in the absence of catalyst. Without catalyst, the tar yield was rather high and the formation rates of $\mathrm{CO}$ and $\mathrm{H}_{2}$ were quite low. On the other hand, when Ni catalysts were used, the yield of tar decreased and the formation rate of gaseous products, especially $\mathrm{H}_{2}$, increased drastically compared to the case of no catalyst. This result indicates that Ni catalysts are effective for the conversion of tar to useful gases such as $\mathrm{CO}$ and hydrogen. It should be noted that the catalytic performance was strongly dependent on support materials.

Table 3 Catalyst performance in steam reforming of tar derived from the pyrolysis of cedar wood over various oxide supported Ni catalysts at 823 $\mathrm{K}[26]$

\begin{tabular}{|c|c|c|c|c|c|c|c|c|c|c|}
\hline \multirow{2}{*}{ Catalyst } & \multicolumn{5}{|c|}{ Formation rate $(\mu \mathrm{mol} / \mathrm{min})$} & \multirow{2}{*}{$\begin{array}{c}\mathrm{H}_{2} / \mathrm{CO} \\
\text { ratio } \\
\end{array}$} & \multirow{2}{*}{$\begin{array}{c}\text { C-conversion } \\
(\%) \\
\end{array}$} & \multirow{2}{*}{ Char $(\%)$} & \multirow{2}{*}{ Coke $(\%)$} & \multirow{2}{*}{$\operatorname{Tar}(\%)$} \\
\hline & $\mathrm{CO}$ & $\mathrm{H}_{2}$ & $\mathrm{CH}_{4}$ & $\mathrm{C}_{2}$ & $\mathrm{CO}_{2}$ & & & & & \\
\hline $\mathrm{Ni}(12) / \mathrm{Al}_{2} \mathrm{O}_{3}$ & 706 & 938 & 157 & 48 & 420 & 1.3 & 59 & 19 & 12.7 & 9.3 \\
\hline $\mathrm{Ni}(12) / \mathrm{ZrO}_{2}$ & 615 & 1222 & 95 & 17 & 559 & 2.0 & 59 & 22 & 6.6 & 12.4 \\
\hline $\mathrm{Ni}(12) / \mathrm{TiO}_{2}$ & 624 & 950 & 142 & 31 & 411 & 1.5 & 53 & 19 & 15.1 & 12.9 \\
\hline $\mathrm{Ni}(12) / \mathrm{CeO}_{2}$ & 565 & 781 & 121 & 40 & 349 & 1.4 & 50 & 20 & 4.3 & 25.7 \\
\hline $\mathrm{Ni}(12) / \mathrm{MgO}$ & 569 & 417 & 142 & 36 & 251 & 0.7 & 45 & 16 & 10.4 & 28.6 \\
\hline No catalyst & 603 & 269 & 132 & 66 & 189 & 0.4 & 45 & 24 & 0.0 & 31.0 \\
\hline
\end{tabular}

Reaction conditions: biomass $60 \mathrm{mg} / \mathrm{min}\left(\mathrm{H}_{2} \mathrm{O}, 9.2 \%\right.$;, $\left.2320 \mu \mathrm{mol} / \mathrm{min} ; \mathrm{H}, 3220 \mu \mathrm{mol} / \mathrm{min} ; \mathrm{O}, 1430 \mu \mathrm{mol} / \mathrm{min}\right), \mathrm{H}_{2} \mathrm{O} / \mathrm{C}=0.5$, catalyst $1.0 \mathrm{~g}, \mathrm{H}_{2}$ reduction at $773 \mathrm{~K}$ for $30 \mathrm{~min}$.

Figure 1(a) compares the yields of the residual tar and coke in steam reforming of tar at $823 \mathrm{~K}$ over various $\mathrm{Ni}$ catalysts. In terms of the residual tar yield, the order of the activity at $823 \mathrm{~K}$ was as follows: $\mathrm{Ni} / \mathrm{Al}_{2} \mathrm{O}_{3}>\mathrm{Ni} / \mathrm{ZrO}_{2}>$ $\mathrm{Ni} / \mathrm{TiO}_{2}>\mathrm{Ni} / \mathrm{CeO}_{2}>\mathrm{Ni} / \mathrm{MgO}>$ no catalyst. The amount of $\mathrm{H}_{2}$ adsorption listed in Table 2 explains the order of the steam reforming activity. Low activity of $\mathrm{Ni} / \mathrm{MgO}$ is also affected by low reduction degree of $\mathrm{Ni}$ species. On the other hand, the coke yield was in the order: $\mathrm{Ni} / \mathrm{TiO}_{2}>\mathrm{Ni} / \mathrm{Al}_{2} \mathrm{O}_{3}>$
$\mathrm{Ni} / \mathrm{MgO}>\mathrm{Ni} / \mathrm{ZrO}_{2}>\mathrm{Ni} / \mathrm{CeO}_{2}$, which cannot be explained by the amount of $\mathrm{H}_{2}$ adsorption, and this suggests that the function of the support oxide is very important. The tar and coke yields on various Ni catalysts are plotted in Fig. 1(d). The coke deposited on the catalyst can be formed by the decomposition of tar and the disproportionation of $\mathrm{CO}$ as a product of steam reforming. When the coke yield increases with decreasing the tar yield, it is thought that the coke is mainly formed by the decomposition of tar. However, in 

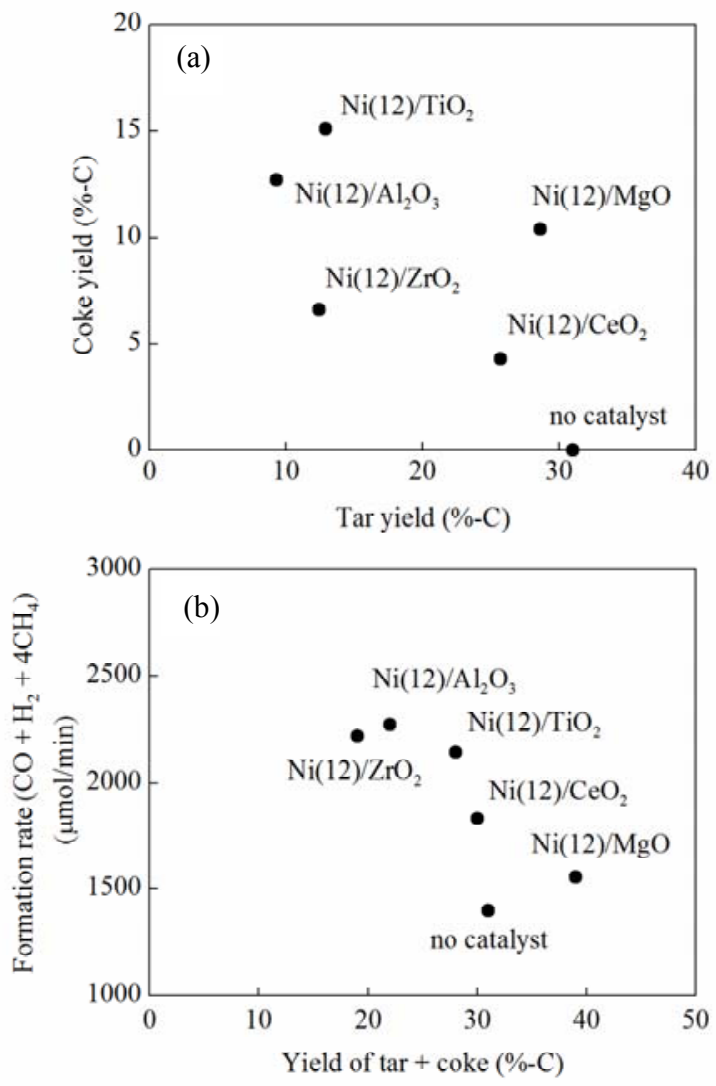

Fig. 1. Formation of tar and coke in steam reforming of tar over various $\mathrm{Ni}$ catalysts (a) and the relation between the yields of tar + coke and formation rate of $\mathrm{CO}+\mathrm{H}_{2}+4 \mathrm{CH}_{4}$ over various $\mathrm{Ni}$ catalysts (b) [26]. Reaction conditions: biomass $60 \mathrm{mg} / \mathrm{min}\left(\mathrm{H}_{2} \mathrm{O}, 9.2 \%\right.$; , $2320 \mu \mathrm{mol} / \mathrm{min} ; \mathrm{H}, 3220 \mu \mathrm{mol} / \mathrm{min}$; O, $1430 \mu \mathrm{mol} / \mathrm{min}$ ), steam 1110 $\mu \mathrm{mol} / \mathrm{min}, \mathrm{H}_{2} \mathrm{O} / \mathrm{C}=0.5,823 \mathrm{~K}, 15 \mathrm{~min}$, catalyst $1.0 \mathrm{~g}, \mathrm{H}_{2}$ reduction at $773 \mathrm{~K}$ for $30 \mathrm{~min}$.

fact, the relation between tar and coke yields was complex, suggesting that the coke is also formed by the $\mathrm{CO}$ disproportionation. In contrast, the relation between the formation rate of $\mathrm{CO}+\mathrm{H}_{2}+4 \mathrm{CH}_{4}$ and the yield of tar + coke (Fig. 1(b)) is clear, and low yield of tar + coke is connected to higher formation rate of the combustible gases. It is concluded that the catalyst with high steam reforming activity and the suppression of coke formation is directly connected to the efficient production of synthesis gas.

Figure 2 shows the TPR profiles of various Ni catalysts. The reduction degree estimated from the results of $\mathrm{H}_{2}$ consumption in TPR profiles is listed in Table 2. Except for $\mathrm{Ni} / \mathrm{MgO}$, the reduction degree of $\mathrm{Ni}$ was almost $100 \%$ and this indicates that all the $\mathrm{Ni}$ was reduced at about $800 \mathrm{~K}$. On the other hand, the reduction degree of $\mathrm{Ni} / \mathrm{MgO}$ was only about $20 \%$. This can be because the strong interaction between $\mathrm{NiO}$ and $\mathrm{MgO}$ decreases catalyst reducibility [47-49]. An important point is that the reduction profile of $\mathrm{Ni}$ is strongly influenced by the support oxides, and Ni species on $\mathrm{CeO}_{2}$ showed high reducibility. The similar behavior

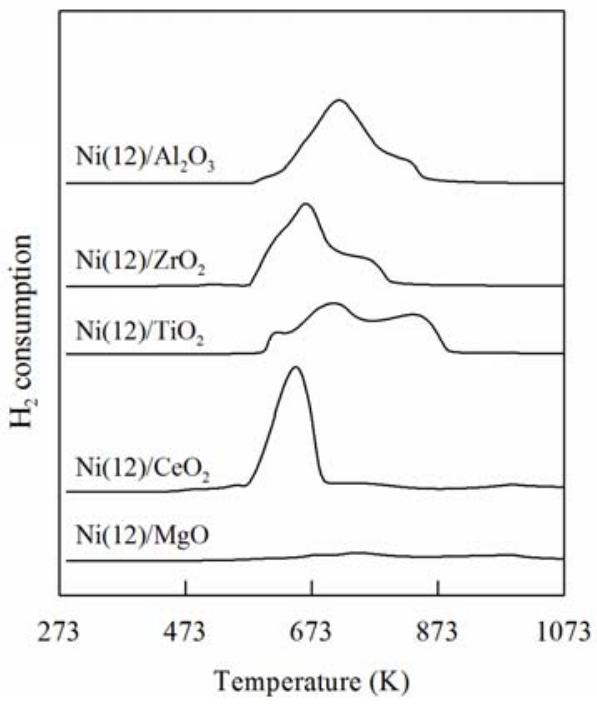

Fig. 2. TPR profiles of various Ni catalysts [26]. Conditions: heating rate, $10 \mathrm{~K} / \mathrm{min}$; room temperature to $973 \mathrm{~K}$, and the temperature was maintained at $973 \mathrm{~K}$ for $30 \mathrm{~min} ; 5 \% \mathrm{H}_{2} / \mathrm{Ar}$, flow rate $30 \mathrm{ml} / \mathrm{min}$.

was also observed in the case of $\mathrm{Rh}-\mathrm{CeO}_{2}$ catalysts [50].

To investigate the catalyst ability for coke removal, we measured the reactivity of coke with catalysts using active carbon as a model compound of coke by means of thermogravimetric analysis (TGA). Figure 3 shows the TGA profiles of active carbon + catalyst in $5 \%$ steam $/ \mathrm{N}_{2}$. Compared to no catalyst, the presence of catalysts promoted steam gasification of active carbon. In particular, $\mathrm{Ni} / \mathrm{CeO}_{2}$ was more effective than the other catalysts. The promotion of reaction between steam and active carbon can cause low coke yield in steam reforming of tar over $\mathrm{Ni} / \mathrm{CeO}_{2}$. This property is due to high redox property of Ce species, and reduction and oxidation of $\mathrm{Ce}$ species proceed in the presence of steam and tar [50].

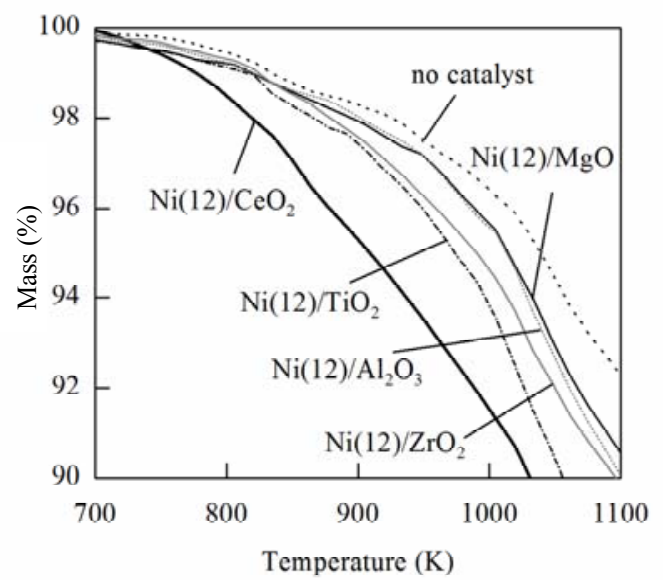

Fig. 3. TGA profiles of active carbon mixed with catalysts under air atmosphere [26]. Conditions: sample, $5 \mathrm{mg}$ active carbon $+5 \mathrm{mg}$ catalyst; heating rate, $15 \mathrm{~K} / \mathrm{min}$, room temperature to $1273 \mathrm{~K}$; air flow rate, $20 \mathrm{ml} / \mathrm{min}$. 


\section{Steam reforming of tar over $\mathrm{Ni} / \mathrm{CeO}_{2} / \mathrm{Al}_{2} \mathrm{O}_{3}$ catalysts $[27,28]$}

As mentioned above, the interaction of $\mathrm{Ni}$ and $\mathrm{CeO}_{2}$ gave high reducibility of $\mathrm{Ni}$ species and the suppression of coke formation. Therefore, the additive effect of $\mathrm{CeO}_{2}$ to $\mathrm{Ni} / \mathrm{Al}_{2} \mathrm{O}_{3}$ was investigated, and in particular, the relation between the $\mathrm{Ni}-\mathrm{CeO}_{2}$ interaction and catalytic performance in the steam reforming of tar was clarified. Two types of $\mathrm{Ni} / \mathrm{CeO}_{2} / \mathrm{Al}_{2} \mathrm{O}_{3}$ catalysts were prepared by the co-impregnation (CI) and sequential impregnation (SI) methods [27,28]. Here, different preparation methods were attempted in order to control the interaction between $\mathrm{Ni}$ and $\mathrm{CeO}_{2}$. In co-impregnation, the $\mathrm{Al}_{2} \mathrm{O}_{3}$ was impregnated with an aqueous solution of $\mathrm{Ni}\left(\mathrm{NO}_{3}\right)_{2} \cdot 6 \mathrm{H}_{2} \mathrm{O}$ and $\mathrm{Ce}\left(\mathrm{NH}_{4}\right)_{2}\left(\mathrm{NO}_{3}\right)_{6}$, followed by drying and calcination at 773 $\mathrm{K}$ for $3 \mathrm{~h}$. In sequential impregnation, the $\mathrm{Al}_{2} \mathrm{O}_{3}$ was impregnated with $\mathrm{Ce}\left(\mathrm{NH}_{4}\right)_{2}\left(\mathrm{NO}_{3}\right)_{6}$ solution, followed by drying and calcination at $773 \mathrm{~K}$ for $3 \mathrm{~h}$, and then impregnated with $\mathrm{Ni}\left(\mathrm{NO}_{3}\right)_{2} \cdot 6 \mathrm{H}_{2} \mathrm{O}$ solution, followed by drying and calcination at $773 \mathrm{~K}$ for $3 \mathrm{~h}$. The loading amounts of $\mathrm{Ni}$ and $\mathrm{CeO}_{2}$ are described in parentheses as mass percent on all the catalysts.

Figure 4 shows the catalytic performances of $\mathrm{Ni} / \mathrm{CeO}_{2} /$ $\mathrm{Al}_{2} \mathrm{O}_{3}$ catalysts in steam reforming of tar at $823 \mathrm{~K}$. On 4 wt $\%$ Ni catalysts, $\mathrm{Ni}(4) / \mathrm{CeO}_{2}(30) / \mathrm{Al}_{2} \mathrm{O}_{3}$ (CI) exhibited higher activity than $\mathrm{Ni}(4) / \mathrm{Al}_{2} \mathrm{O}_{3}$ and $\mathrm{Ni}(4) / \mathrm{CeO}_{2}(30) / \mathrm{Al}_{2} \mathrm{O}_{3}$ (SI) catalysts, and at the same time, $\mathrm{Ni}(4) / \mathrm{CeO}_{2}(30) / \mathrm{Al}_{2} \mathrm{O}_{3}$ (CI) also showed higher resistance to coke formation. Similar tendency was also observed on $12 \mathrm{wt} \% \mathrm{Ni}$ catalysts. These results demonstrate that the co-impregnation is an

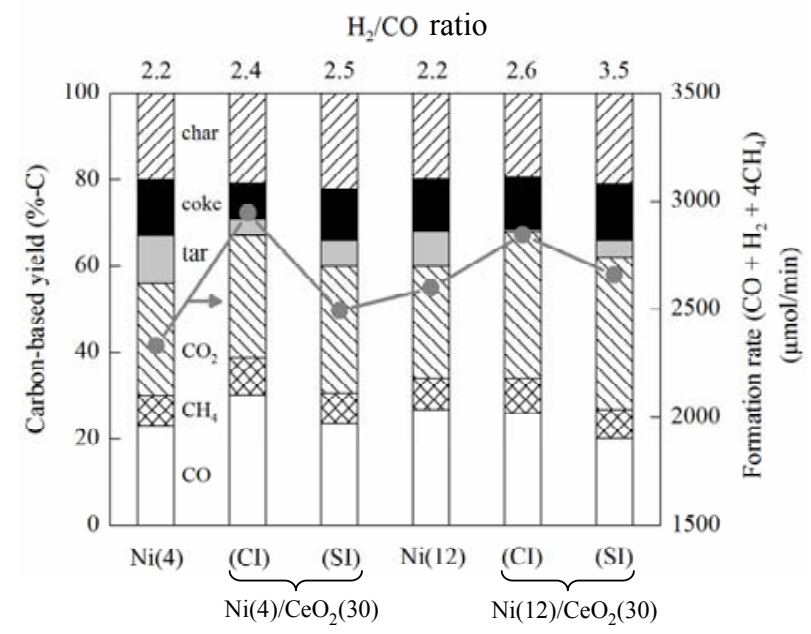

Fig. 4. Catalytic performances of $\mathrm{Ni} / \mathrm{CeO}_{2} / \mathrm{Al}_{2} \mathrm{O}_{3}$ in steam reforming of $\operatorname{tar}[27,28]$. Conditions: biomass, $60 \mathrm{mg} / \mathrm{min}\left(\mathrm{H}_{2} \mathrm{O}, 10.4 \%\right.$;, 2191 $\mu \mathrm{mol} / \mathrm{min} ; \mathrm{H}, 3543 \mu \mathrm{mol} / \mathrm{min} ; \mathrm{O}, 1478 \mu \mathrm{mol} / \mathrm{min}) ;$ steam, 1110 $\mu \mathrm{mol} / \mathrm{min}$, (added $\left.\mathrm{H}_{2} \mathrm{O}\right) / \mathrm{C}=0.5$; reaction temperature, $823 \mathrm{~K}$; reaction time, $15 \mathrm{~min}$; catalyst, $1.0 \mathrm{~g} ; \mathrm{H}_{2}$ reduction at $773 \mathrm{~K}$ for $30 \mathrm{~min}$. Loading amount: $\mathrm{Ni}, 4$ and $12 \mathrm{wt} \% ; \mathrm{CeO}_{2}, 30 \mathrm{wt} \%$. effective preparation method for $\mathrm{Ni} / \mathrm{CeO}_{2} / \mathrm{Al}_{2} \mathrm{O}_{3}$.

Figure 5 shows TPR profiles of $\mathrm{Ni} / \mathrm{Al}_{2} \mathrm{O}_{3}$ and $\mathrm{Ni} / \mathrm{CeO}_{2} /$ $\mathrm{Al}_{2} \mathrm{O}_{3}$ catalysts. On $\mathrm{Ni}(4) / \mathrm{Al}_{2} \mathrm{O}_{3}$, the $\mathrm{H}_{2}$ consumption was observed in the temperature range between 630 and $850 \mathrm{~K}$. In the presence of $\mathrm{CeO}_{2}$, the peak of $\mathrm{H}_{2}$ consumption was shifted to lower temperature. The shift on $\mathrm{Ni}(4) / \mathrm{CeO}_{2}(30) /$ $\mathrm{Al}_{2} \mathrm{O}_{3}$ (CI) was more significant than that on $\mathrm{Ni}(4) /$ $\mathrm{CeO}_{2}(30) / \mathrm{Al}_{2} \mathrm{O}_{3}$ (SI). A similar phenomenon was also observed on the $12 \mathrm{wt} \% \mathrm{Ni}$ catalysts. The lower temperature shift of $\mathrm{H}_{2}$ consumption peak by the addition of $\mathrm{CeO}_{2}$ can be explained by the interaction between $\mathrm{Ni}$ species and $\mathrm{CeO}_{2}$. The larger shift on $\mathrm{Ni} / \mathrm{CeO}_{2} / \mathrm{Al}_{2} \mathrm{O}_{3}(\mathrm{CI})$ than that on $\mathrm{Ni} / \mathrm{CeO}_{2} / \mathrm{Al}_{2} \mathrm{O}_{3}$ (SI) can be interpreted by the stronger interaction between $\mathrm{Ni}$ and $\mathrm{CeO}_{2}$ introduced by the co-impregnation method. Another important point is that the Ni-based reduction degree on the CI catalysts is higher than that on the SI catalysts, and especially, the reduction degree of $\mathrm{Ni}(4) / \mathrm{CeO}_{2}(30) / \mathrm{Al}_{2} \mathrm{O}_{3}(\mathrm{CI})$ was high (Table 4).

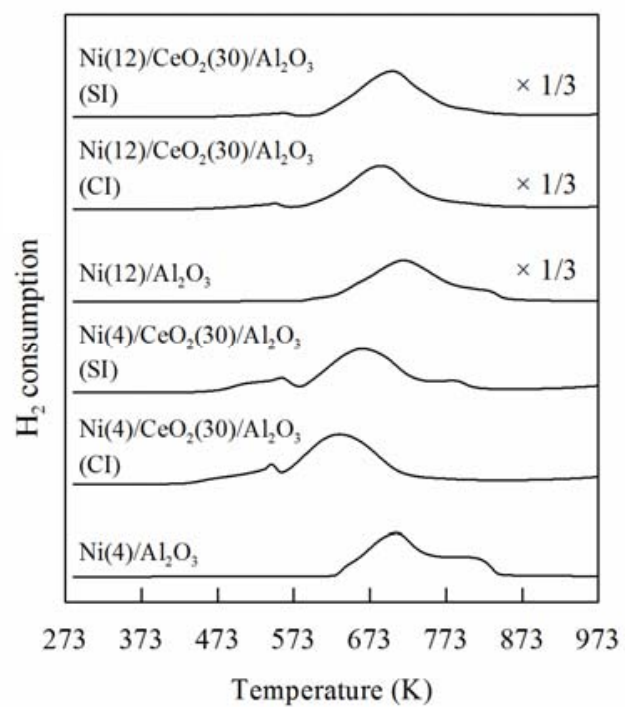

Fig. 5. TPR profiles of $\mathrm{Ni} / \mathrm{CeO}_{2} / \mathrm{Al}_{2} \mathrm{O}_{3}$ catalysts [27,28]. Conditions: heating rate, $10 \mathrm{~K} / \mathrm{min}$; room temperature to $973 \mathrm{~K}$, and the temperature was maintained at $973 \mathrm{~K}$ for $10 \mathrm{~min} ; 5 \% \mathrm{H}_{2} / \mathrm{Ar}, 30 \mathrm{ml} / \mathrm{min}$; sample amount, $50 \mathrm{mg}$.

Assuming that the $\mathrm{CeO}_{2}$ around $\mathrm{Ni}$ can be reduced more easily, these results also support the stronger interaction between $\mathrm{Ni}$ and $\mathrm{CeO}_{2}$ on $\mathrm{Ni}(4) / \mathrm{CeO}_{2}(30) / \mathrm{Al}_{2} \mathrm{O}_{3}(\mathrm{CI})$. The characterization by TEM and EXAFS analysis showed that the particle size of $\mathrm{Ni}$ over $\mathrm{Ni}(4) / \mathrm{CeO}_{2}(30) / \mathrm{Al}_{2} \mathrm{O}_{3}$ (CI) was smaller than those over $\mathrm{Ni}(4) / \mathrm{Al}_{2} \mathrm{O}_{3}$ and $\mathrm{Ni}(4) / \mathrm{CeO}_{2}(30) /$ $\mathrm{Al}_{2} \mathrm{O}_{3}$ (SI) [28]. Nevertheless, the amount of $\mathrm{H}_{2}$ adsorption on $\mathrm{Ni}(4) / \mathrm{CeO}_{2}(30) / \mathrm{Al}_{2} \mathrm{O}_{3}(\mathrm{CI})$ was a little smaller than those on the other two catalysts (Table 4). The inconsistence between the results of TEM and EXAFS and that of $\mathrm{H}_{2}$ adsorption can be explained by covering $\mathrm{Ni}$ with $\mathrm{CeO}_{2}$ over $\mathrm{Ni}(4) / \mathrm{CeO}_{2}(30) / \mathrm{Al}_{2} \mathrm{O}_{3}$ (CI), which also supports that the strong interaction between $\mathrm{Ni}$ and $\mathrm{CeO}_{2}$ can be realized by 
Table 4 Physicochemical properties of $\mathrm{Ni} / \mathrm{CeO}_{2} / \mathrm{Al}_{2} \mathrm{O}_{3}$ catalysts $[27,28]$

\begin{tabular}{|c|c|c|c|c|}
\hline Catalyst & $\begin{array}{c}\text { BET } \\
\text { surface } \\
\text { area } \\
\left(\mathrm{m}^{2} / \mathrm{g}_{\mathrm{cat}}\right)\end{array}$ & $\begin{array}{c}\mathrm{H}_{2} \\
\text { consumption } \\
\left(10^{-3} \mathrm{~mol} / \mathrm{g}_{\mathrm{cat}}\right)\end{array}$ & $\mathrm{H}_{2} / \mathrm{Ni}^{\mathrm{b}}$ & $\begin{array}{c}\mathrm{H}_{2} \\
\text { adsorption }^{\mathrm{c}} \\
(\mathrm{H} / \mathrm{Ni})\end{array}$ \\
\hline $\mathrm{Ni}(4) / \mathrm{Al}_{2} \mathrm{O}_{3}$ & 9 & 0.71 & 1.04 & 0.045 \\
\hline $\mathrm{Ni}(4) / \mathrm{CeO}_{2}(30) / \mathrm{Al}_{2} \mathrm{O}_{3}(\mathrm{CI})$ & 30 & 1.01 & 1.56 & 0.031 \\
\hline $\mathrm{Ni}(4) / \mathrm{CeO}_{2}(30) / \mathrm{Al}_{2} \mathrm{O}_{3}(\mathrm{SI})$ & 13 & 0.95 & 1.39 & 0.042 \\
\hline $\mathrm{Ni}(12) / \mathrm{Al}_{2} \mathrm{O}_{3}$ & 13 & 2.11 & 1.03 & 0.030 \\
\hline $\mathrm{Ni}(12) / \mathrm{CeO}_{2}(30) / \mathrm{Al}_{2} \mathrm{O}_{3}(\mathrm{CI})$ & 22 & 2.36 & 1.15 & 0.021 \\
\hline $\mathrm{Ni}(12) / \mathrm{CeO}_{2}(30) / \mathrm{Al}_{2} \mathrm{O}_{3}(\mathrm{SI})$ & 13 & 2.26 & 1.10 & 0.019 \\
\hline
\end{tabular}

${ }^{\mathrm{a}} \mathrm{H}_{2}$ consumption below $773 \mathrm{~K}$ in TPR profiles.

${ }^{\mathrm{b}}$ Calculated by $\left(\mathrm{H}_{2}\right.$ consumption)/(loading amount of $\mathrm{Ni}$ ), assuming that $\mathrm{Ni}^{2+}+\mathrm{H}_{2} \rightarrow \mathrm{Ni}^{0}+2 \mathrm{H}^{+}$.

${ }^{\mathrm{c}} \mathrm{H}_{2}$ adsorption is total adsorption at room temperature, and $\mathrm{H} / \mathrm{Ni}=1$ is assumed.

the co-impregnation method. According to the catalyst characterization, the particle size of $\mathrm{Ni}$ metal and $\mathrm{CeO}_{2}$ was about 7 and $8 \mathrm{~nm}$, respectively [28], and the TEM image suggests that $100 \mathrm{~nm} \mathrm{Ni}-\mathrm{CeO}_{2}$ nanocomposite consisted of 7-8 nm Ni metal and $\mathrm{CeO}_{2}$ particles. The formation of nanocomposite enables large interface of $\mathrm{Ni}-\mathrm{CeO}_{2}$. This property can be related to the excellent performance in steam reforming of tar. It is suggested that $\mathrm{CeO}_{2}$ can supply oxygen atom to the adsorbed species on Ni metal surface at the interface. The carbonaceous reaction intermediate species adsorbed on Ni metal surface can react with oxygen atom supplied from neighboring $\mathrm{CeO}_{2}$, resulting in high catalytic activity and low coke formation. The role of the interface between $\mathrm{Ni}$ and $\mathrm{CeO}_{2}$ is illustrated in Fig. 6 .

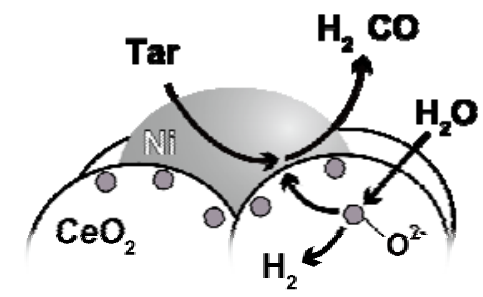

Fig. 6. Role of the $\mathrm{Ni}-\mathrm{CeO}_{2}$ interface on $\mathrm{Ni}-\mathrm{CeO}_{2}$ nanocomposite in steam reforming of tar.

\section{Steam reforming of tar over $\mathrm{Ni} / \mathrm{CeO}_{2} / \mathrm{Al}_{2} \mathrm{O}_{3}$ modified with noble metals $[29,30]$}

It has been reported that the modification of $\mathrm{Ni}$ catalysts for steam reforming of hydrocarbons with a small amount of noble metals enhances the catalytic performance remarkably from the aspects of activity, suppression of coke formation, catalyst reducibility, catalyst activation, and so on [51-62]. $\mathrm{Pt}, \mathrm{Pd}, \mathrm{Rh}$, and $\mathrm{Ru}$ were loaded on $\mathrm{Ni}(4) / \mathrm{CeO}_{2}(30) / \mathrm{Al}_{2} \mathrm{O}_{3}$ (CI) using an aqueous solution of $\mathrm{Pt}\left(\mathrm{NO}_{2}\right)_{2}\left(\mathrm{NH}_{3}\right)_{2}$, $\mathrm{Pd}\left(\mathrm{NO}_{3}\right)_{2}, \quad \mathrm{Rh}\left(\mathrm{NO}_{3}\right)_{3}$, and $\mathrm{Ru}(\mathrm{NO})\left(\mathrm{NO}_{3}\right)_{3}$, respectively
[29,30]. After impregnation, the sample was dried, followed by calcination at $773 \mathrm{~K}$ for $3 \mathrm{~h}$. The loading amount of each component is described in parentheses as mass percent on all the catalysts.

Figure 7 shows the catalytic performances of noble metal-modified $\mathrm{Ni}(4) / \mathrm{CeO}_{2}(30) / \mathrm{Al}_{2} \mathrm{O}_{3}$ catalysts in steam reforming of tar at $823 \mathrm{~K}$. Here, the catalysts without $\mathrm{H}_{2}$ reduction were compared in order to evaluate the effect of noble metals on the self-activation. The modification by noble metals improved the catalytic activity. Among noble metals investigated, $\mathrm{Pt}$ was the most effective. On $\mathrm{Pt}(0.1) /$ $\mathrm{Ni}(4) / \mathrm{CeO}_{2}(30) / \mathrm{Al}_{2} \mathrm{O}_{3}$, the tar yield was almost zero. This performance is higher than that of $\mathrm{Ni}(4) / \mathrm{CeO}_{2}(30) / \mathrm{Al}_{2} \mathrm{O}_{3}$ with reduction pretreatment (Fig. 4). The promoting effect of Pt was so significant that the addition of a very small amount of $\mathrm{Pt}$ such as $0.01 \mathrm{wt} \%$ to the $\mathrm{Ni}(4) / \mathrm{CeO}_{2}(30) / \mathrm{Al}_{2} \mathrm{O}_{3}$ catalyst also enhanced the performance drastically. We have verified that $\mathrm{Pt}(0.1) / \mathrm{CeO}_{2}(30) / \mathrm{Al}_{2} \mathrm{O}_{3}$ showed much lower performance than $\mathrm{Ni}(4) / \mathrm{CeO}_{2}(30) / \mathrm{Al}_{2} \mathrm{O}_{3}$ and $\mathrm{Pt}(0.1) / \mathrm{Ni}(4) /$ $\mathrm{CeO}_{2}(30) / \mathrm{Al}_{2} \mathrm{O}_{3}$ [30]. Therefore, the activity of $\mathrm{Pt} / \mathrm{Ni}(4) /$ $\mathrm{CeO}_{2}(30) / \mathrm{Al}_{2} \mathrm{O}_{3}$ was mainly due to $\mathrm{Ni}$ species and the addition of Pt enhanced the activity of $\mathrm{Ni}$ species.

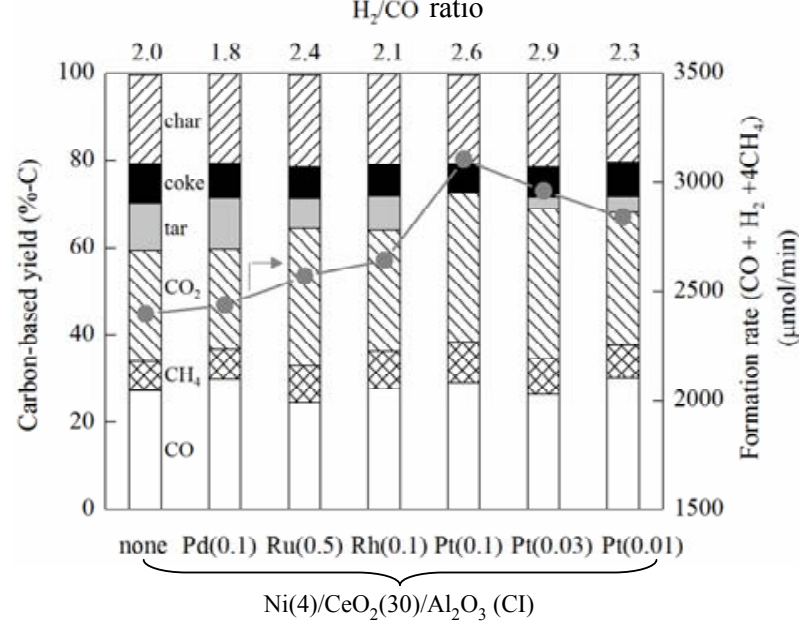

Fig. 7. Catalytic performance in steam reforming of tar over noble metal-modified $\mathrm{Ni}(4) / \mathrm{CeO}_{2}(30) / \mathrm{Al}_{2} \mathrm{O}_{3}$ (CI) [30]. Reaction conditions: biomass, $60 \mathrm{mg} / \mathrm{min}\left(\mathrm{H}_{2} \mathrm{O}\right.$ 9.2\%; C, $2191 \mu \mathrm{mol} / \mathrm{min} ; \mathrm{H}, 3543$ $\mu \mathrm{mol} / \mathrm{min}$; $\mathrm{O}, 1475 \mu \mathrm{mol} / \mathrm{min})$; steam, $1110 \mu \mathrm{mol} / \mathrm{min}$, (added $\left.\mathrm{H}_{2} \mathrm{O}\right) / \mathrm{C}$ $=0.5$; reaction temperature, $823 \mathrm{~K}$; reaction time, $15 \mathrm{~min}$; catalyst, 1.0 g; without reduction. Loading amount: $\mathrm{Ni}, 4 \mathrm{wt} \% ; \mathrm{CeO}_{2}, 30 \mathrm{wt} \%$; $\mathrm{Pd}$, $0.1 \mathrm{wt} \%$; Ru, $0.5 \mathrm{wt} \%$; Rh, $0.1 \mathrm{wt} \%$; Pt, $0.01-0.1 \mathrm{wt} \%$.

Figure 8 shows the TPR profiles of $\mathrm{Ni}(4) / \mathrm{CeO}_{2}(30) / \mathrm{Al}_{2} \mathrm{O}_{3}$ modified with noble metals. The addition of $0.1 \mathrm{wt} \% \mathrm{Pt}$ increased hydrogen consumption at $520 \mathrm{~K}$ and decreased that at $620 \mathrm{~K}$. On the other hand, no peaks were observed on $\mathrm{Pt}(0.1) / \mathrm{CeO}_{2}(30) / \mathrm{Al}_{2} \mathrm{O}_{3}$ around $520 \mathrm{~K}$. These indicate that the peak at $520 \mathrm{~K}$ on $\mathrm{Pt}(0.1) / \mathrm{Ni}(4) / \mathrm{CeO}_{2}(30) / \mathrm{Al}_{2} \mathrm{O}_{3}$ can be assigned to the reduction of $\mathrm{NiO}$ promoted by the Pt addition. From the comparison between the TPR profiles of 


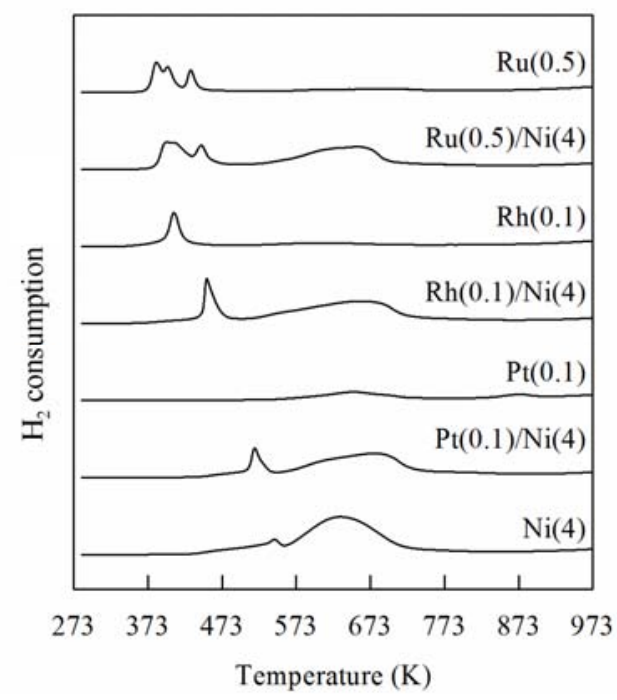

Fig. 8. TPR profiles of noble metal-modified $\mathrm{Ni}(4) / \mathrm{CeO}_{2}(30) / \mathrm{Al}_{2} \mathrm{O}_{3}$ (CI) [30]. Conditions: heating rate $10 \mathrm{~K} / \mathrm{min}$, room temperature to 973 $\mathrm{K} ; 5 \% \mathrm{H}_{2} / \mathrm{Ar}, 30 \mathrm{ml} / \mathrm{min}$; sample amount, $50 \mathrm{mg}$. Loading amount: $\mathrm{Ni}$, $4 \mathrm{wt} \%$; Pt, $0.1 \mathrm{wt} \% ; \mathrm{Rh}, 0.1 \mathrm{wt} \% ; \mathrm{Ru}, 0.5 \mathrm{wt} \%$.

$\mathrm{M} / \mathrm{Ni} / \mathrm{CeO}_{2} / \mathrm{Al}_{2} \mathrm{O}_{3}$ and $\mathrm{M} / \mathrm{CeO}_{2} / \mathrm{Al}_{2} \mathrm{O}_{3}(\mathrm{M}=\mathrm{Rh}$ and $\mathrm{Ru})$, the lower temperature peaks below $500 \mathrm{~K}$ may be assigned to the reduction of $\mathrm{CeO}_{2}$ promoted by the presence of $\mathrm{Rh}$ and $\mathrm{Ru}$, and these behaviors are different from the case of Pt. These results suggest that $\mathrm{Pt}$ tends to interact with $\mathrm{NiO}$ species, and other noble metals tend to interact with $\mathrm{CeO}_{2}$. This was supported by EXAFS results that Pt-Ni alloy was formed [30], while $\mathrm{Rh}, \mathrm{Ru}$, and Pd did not alloy with $\mathrm{Ni}$. Combination of catalytic performance and characterization results suggests that high performance of $\mathrm{Pt} / \mathrm{Ni} / \mathrm{CeO}_{2} / \mathrm{Al}_{2} \mathrm{O}_{3}$ can be due to the strong interaction between $\mathrm{Pt}$ and $\mathrm{Ni}$ to form Pt-Ni alloy.

In addition, the coke was formed on $\mathrm{Pt} / \mathrm{Ni} / \mathrm{CeO}_{2} / \mathrm{Al}_{2} \mathrm{O}_{3}$ during the reaction as shown in Fig. 7, and this can deactivate the catalyst. The deposited coke was removed by the combustion with air, but one problem is the aggregation of Ni metal particles during the reaction and regeneration procedure [31]. Therefore, the re-dispersion of Ni metal particles by the catalyst regeneration is thought to be necessary. It has been known that the interaction of $\mathrm{Ni}$ and $\mathrm{MgO}$ is strong and $\mathrm{NiO}-\mathrm{MgO}$ solid solution is easily formed. At the same time, the reduction of the $\mathrm{NiO}-\mathrm{MgO}$ solid solution gives small $\mathrm{Ni}$ metal particles $[48,62,63]$. We expect that the re-dispersion of aggregated $\mathrm{Ni}$ metal particles can be attached by the addition of $\mathrm{MgO}$ to the catalyst via formation and reduction of $\mathrm{NiO}-\mathrm{MgO}$ solid solution.

\section{Steam reforming of tar over $\mathrm{Pt} / \mathrm{Ni} / \mathrm{CeO}_{2} / \mathrm{MgO} / \mathrm{Al}_{2} \mathrm{O}_{3}$ [31]}

$\mathrm{Ni} / \mathrm{CeO}_{2} / \mathrm{MgO} / \mathrm{Al}_{2} \mathrm{O}_{3}$ (CI) was prepared by the co-impregnation method using an aqueous solution of $\mathrm{Ni}\left(\mathrm{NO}_{3}\right)_{2} \cdot 6 \mathrm{H}_{2} \mathrm{O}, \mathrm{Ce}\left(\mathrm{NH}_{4}\right)_{2}\left(\mathrm{NO}_{3}\right)_{6}$, and $\mathrm{Mg}\left(\mathrm{NO}_{3}\right)_{2} \cdot 6 \mathrm{H}_{2} \mathrm{O}$ [31] in a similar way for $\mathrm{Ni} / \mathrm{CeO}_{2} / \mathrm{Al}_{2} \mathrm{O}_{3}(\mathrm{CI}) . \mathrm{Pt} / \mathrm{Ni} / \mathrm{CeO}_{2} /$ $\mathrm{MgO} / \mathrm{Al}_{2} \mathrm{O}_{3}$ (CI) was prepared by the impregnation of aqueous solution of $\mathrm{Pt}\left(\mathrm{NO}_{2}\right)_{2}\left(\mathrm{NH}_{3}\right)_{2}$ on $\mathrm{Ni} / \mathrm{CeO}_{2} / \mathrm{MgO} /$ $\mathrm{Al}_{2} \mathrm{O}_{3}(\mathrm{CI})$ in the same way for $\mathrm{Pt} / \mathrm{Ni} / \mathrm{CeO}_{2} / \mathrm{Al}_{2} \mathrm{O}_{3}(\mathrm{CI})$. As a reference, $\mathrm{Pt} / \mathrm{Ni} / \mathrm{MgO} / \mathrm{Al}_{2} \mathrm{O}_{3}(\mathrm{CI})$ was prepared in a similar way. The loading amount of each component is described in parentheses as mass percent on all the catalysts. Figure 9 shows the catalytic performance of $\mathrm{Pt}(0.1) / \mathrm{Ni}(12) /$ $\mathrm{CeO}_{2}(15) / \mathrm{MgO}(2) / \mathrm{Al}_{2} \mathrm{O}_{3}$ together with those of $\mathrm{Pt}(0.1) /$ $\mathrm{Ni}(12) / \mathrm{CeO}_{2}(15) / \mathrm{Al}_{2} \mathrm{O}_{3}$ and $\mathrm{Pt}(0.1) / \mathrm{Ni}(12) / \mathrm{MgO}(2) / \mathrm{Al}_{2} \mathrm{O}_{3}$.

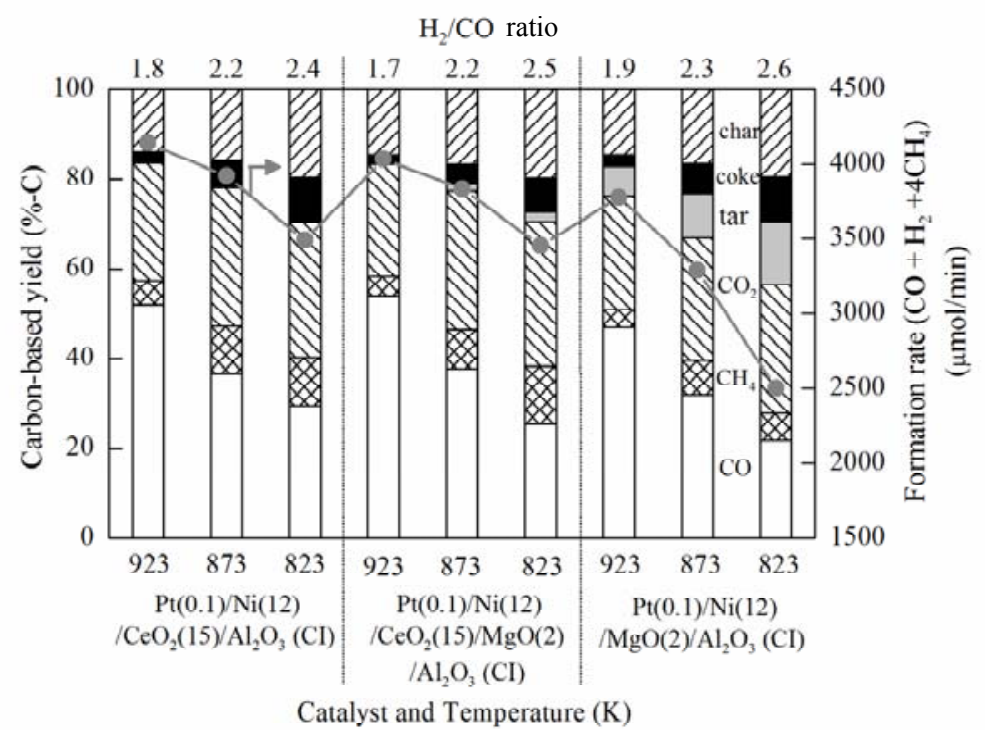

Fig. 9. Catalytic performance in steam reforming of tar on $\mathrm{Pt}(0.1) / \mathrm{Ni}(12) / \mathrm{CeO}_{2}(15) / \mathrm{Al}_{2} \mathrm{O}_{3}, \mathrm{Pt}(0.1) / \mathrm{Ni}(12) / \mathrm{CeO} 2(15) / \mathrm{MgO}(2) / \mathrm{Al}_{2} \mathrm{O}_{3}$, and $\mathrm{Pt}(0.1) / \mathrm{Ni}(12) / \mathrm{MgO}(2) / \mathrm{Al}_{2} \mathrm{O}_{3}$ [31]. Conditions: biomass, $60 \mathrm{mg} / \mathrm{min}\left(\mathrm{H}_{2} \mathrm{O}, 9.2 \%\right.$;, $\left.2191 \mu \mathrm{mol} / \mathrm{min} ; \mathrm{H}, 3543 \mu \mathrm{mol} / \mathrm{min} ; \mathrm{O}, 1475 \mu \mathrm{mol} / \mathrm{min}\right)$; steam, $1110 \mu \mathrm{mol} / \mathrm{min}$, (added $\left.\mathrm{H}_{2} \mathrm{O}\right) / \mathrm{C}=0.5$; reaction time, $15 \mathrm{~min}$; catalyst, $1.0 \mathrm{~g} ; \mathrm{H}_{2}$ reduction at $773 \mathrm{~K}$ for $30 \mathrm{~min}$. 
Judging from the tar yield, the order of the catalytic activity is as follows: $\mathrm{Pt}(0.1) / \mathrm{Ni}(12) / \mathrm{CeO}_{2}(15) / \mathrm{Al}_{2} \mathrm{O}_{3} \approx \mathrm{Pt}(0.1) /$ $\mathrm{Ni}(12) / \mathrm{CeO}_{2}(15) / \mathrm{MgO}(2) / \mathrm{Al}_{2} \mathrm{O}_{3}>\mathrm{Pt}(0.1) / \mathrm{Ni}(12) / \mathrm{MgO}(2) /$ $\mathrm{Al}_{2} \mathrm{O}_{3}$. It should be noted that the addition of $\mathrm{MgO}$ to $\mathrm{Pt}(0.1) / \mathrm{Ni}(12) / \mathrm{CeO}_{2}(2) / \mathrm{Al}_{2} \mathrm{O}_{3}$ suppressed the carbon formation to some extent. Although the details are not shown here, $\mathrm{Ni}(12) / \mathrm{CeO}_{2}(15) / \mathrm{MgO}(2) / \mathrm{Al}_{2} \mathrm{O}_{3}$ showed lower activity than $\mathrm{Ni}(12) / \mathrm{MgO}(2) / \mathrm{Al}_{2} \mathrm{O}_{3}$. However, it is found that the performance of $\mathrm{Pt}(0.1) / \mathrm{Ni}(12) / \mathrm{CeO}_{2}(15) / \mathrm{MgO}(2) / \mathrm{Al}_{2} \mathrm{O}_{3}$ became comparable to that of $\mathrm{Pt}(0.1) / \mathrm{Ni}(12) / \mathrm{CeO}_{2}(15) /$ $\mathrm{Al}_{2} \mathrm{O}_{3}$ in the presence of a small amount of added $\mathrm{Pt}$.

Figure 10 displays the formation rate of the gaseous products with time on stream over $\mathrm{Pt}(0.1) / \mathrm{Ni}(12) / \mathrm{CeO}_{2}(15) /$ $\mathrm{MgO}(2) / \mathrm{Al}_{2} \mathrm{O}_{3}$ without $\mathrm{H}_{2}$ reduction pretreatment. The formation rate increased with time on stream and it reached the similar value to that over the catalyst with $\mathrm{H}_{2}$ reduction pretreatment after $12 \mathrm{~min}$. This result indicates that the tar de-

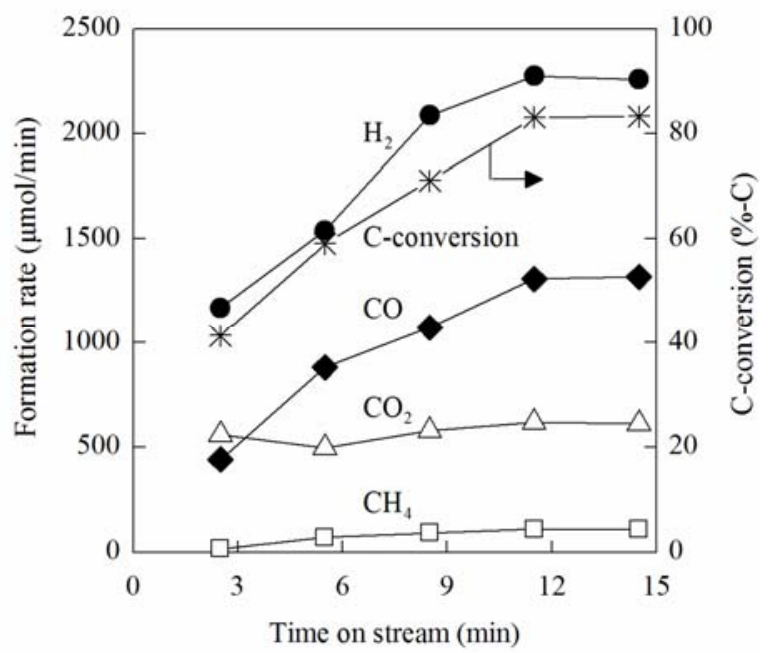

Fig. 10. Catalytic performance with time on stream over $\mathrm{Pt}(0.1) / \mathrm{Ni}(12) / \mathrm{CeO}_{2}(15) / \mathrm{MgO}(2) / \mathrm{Al}_{2} \mathrm{O}_{3}$ (CI) without $\mathrm{H}_{2}$ reduction [31]. Reaction conditions: biomass, $60 \mathrm{mg} / \mathrm{min}\left(\mathrm{H}_{2} \mathrm{O}, 9.2 \%\right.$; C, 2191 $\mu \mathrm{mol} / \mathrm{min} ; \mathrm{H}, 3543 \mu \mathrm{mol} / \mathrm{min} ; \mathrm{O}, 1475 \mu \mathrm{mol} / \mathrm{min})$; steam, 1110 $\mu \mathrm{mol} / \mathrm{min},\left(\right.$ added $\left.\mathrm{H}_{2} \mathrm{O}\right) / \mathrm{C}=0.5$; reaction temperature, $923 \mathrm{~K}$; catalyst, $1.0 \mathrm{~g}$.

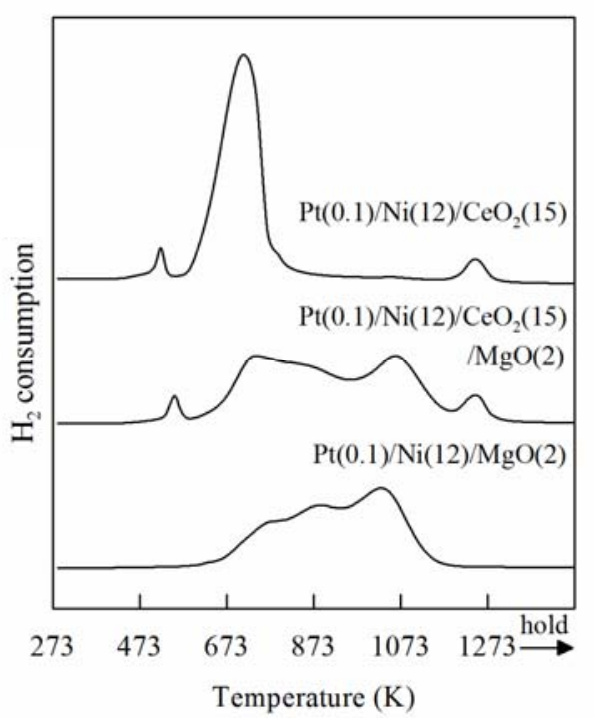

Fig. 11. $\mathrm{TPR}$ profiles of $\mathrm{Pt}(0.1) / \mathrm{Ni}(12) / \mathrm{CeO}_{2}(15) / \mathrm{MgO}(2) / \mathrm{Al}_{2} \mathrm{O}_{3}$, $\mathrm{Pt}(0.1) / \mathrm{Ni}(12) / \mathrm{CeO}_{2}(15) / \mathrm{Al}_{2} \mathrm{O}_{3}$, and $\mathrm{Pt}(0.1) / \mathrm{Ni}(12) / \mathrm{MgO}(2) / \mathrm{Al}_{2} \mathrm{O}_{3}$ catalysts [31]. Conditions: heating rate, $10 \mathrm{~K} / \mathrm{min}$; room temperature to $1273 \mathrm{~K}$, and the temperature was maintained at $1273 \mathrm{~K}$ for $30 \mathrm{~min} ; 5 \%$ $\mathrm{H}_{2} / \mathrm{Ar}, 30 \mathrm{ml} / \mathrm{min}$; sample amount, $200 \mathrm{mg}$.

rived from the pyrolysis of cedar wood can reduce the catalyst, although the reduction of $\mathrm{Pt}(0.1) / \mathrm{Ni}(12) / \mathrm{CeO}_{2}(15) /$ $\mathrm{MgO}(2) / \mathrm{Al}_{2} \mathrm{O}_{3}$ was not so rapid as described below. This behavior indicates that the $\mathrm{Pt}(0.1) / \mathrm{Ni}(12) / \mathrm{CeO}_{2}(15) /$ $\mathrm{MgO}(2) / \mathrm{Al}_{2} \mathrm{O}_{3}$ catalyst can be activated automatically by the reactants, which is regarded as the ability of the self-activation property [57,60-62].

Figure 11 shows the TPR profiles of the calcined catalysts. The amount of $\mathrm{H}_{2}$ consumption below $773 \mathrm{~K}$ and the Ni-based reduction degree estimated from the amount of $\mathrm{H}_{2}$ consumption are listed in Table 5. On $\mathrm{Pt}(0.1) / \mathrm{Ni}(12) /$ $\mathrm{CeO}_{2}(15) / \mathrm{Al}_{2} \mathrm{O}_{3}$, the reduction proceeds mainly below 773 $\mathrm{K}$. The profile of $\mathrm{Pt}(0.1) / \mathrm{Ni}(12) / \mathrm{CeO}_{2}(15) / \mathrm{MgO}(2) / \mathrm{Al}_{2} \mathrm{O}_{3}$ was greatly different from that of $\mathrm{Pt}(0.1) / \mathrm{Ni}(12) / \mathrm{CeO}_{2}(15) /$ $\mathrm{Al}_{2} \mathrm{O}_{3}$, and this can be explained by the effect of the presence of $\mathrm{MgO}$. On $\mathrm{Pt}(0.1) / \mathrm{Ni}(12) / \mathrm{CeO}_{2}(15) / \mathrm{MgO}(2) / \mathrm{Al}_{2} \mathrm{O}_{3}$,

Table 5 Physicochemical properties of $\mathrm{Pt} / \mathrm{Ni} / \mathrm{CeO}_{2} / \mathrm{Al}_{2} \mathrm{O}_{3}, \mathrm{Pt} / \mathrm{Ni} / \mathrm{CeO}_{2} / \mathrm{MgO} / \mathrm{Al}_{2} \mathrm{O}_{3}$, and $\mathrm{Pt} / \mathrm{Ni} / \mathrm{MgO} / \mathrm{Al}_{2} \mathrm{O}_{3}$ catalysts after $\mathrm{H}_{2}$ reduction at $773 \mathrm{~K}$ [31]

\begin{tabular}{|c|c|c|c|c|c|c|}
\hline Catalyst & $\begin{array}{l}\text { BET surface } \\
\text { area }\left(\mathrm{m}^{2} / \mathrm{g}_{\text {cat }}\right)\end{array}$ & $\begin{array}{c}\mathrm{H}_{2} \text { consumption } \\
\left(10^{-3} \mathrm{~mol} / \mathrm{g}_{\text {cat }}\right) \\
\end{array}$ & $\begin{array}{l}\text { Ni-based reduc- } \\
\text { tion degree }{ }^{\mathrm{b}}(\%)\end{array}$ & $\begin{array}{l}\mathrm{H}_{2} \text { adsorption }^{\mathrm{c}} \\
\left(10^{-6} \mathrm{~mol} / \mathrm{g}_{\text {cat }}\right)\end{array}$ & $\begin{array}{c}\text { Dispersion }^{\mathrm{d}} \\
(\%) \\
\end{array}$ & $\begin{array}{l}\text { Particle size of } \\
\text { Ni metal }^{\mathrm{e}}(\mathrm{nm})\end{array}$ \\
\hline $\mathrm{Pt}(0.1) / \mathrm{Ni}(12) / \mathrm{CeO}_{2}(15) / \mathrm{Al}_{2} \mathrm{O}_{3}(\mathrm{CI})$ & 18.8 & 1.51 & 96 & 4.2 & 5.6 & 17.5 \\
\hline $\mathrm{Pt}(0.1) / \mathrm{Ni}(12) / \mathrm{CeO}_{2}(15) / \mathrm{MgO}(2) / \mathrm{Al}_{2} \mathrm{O}_{3}(\mathrm{CI})$ & 19.2 & 0.47 & 30 & 3.9 & 16.6 & 5.9 \\
\hline $\mathrm{Pt}(0.1) / \mathrm{Ni}(12) / \mathrm{MgO}(2) / \mathrm{Al}_{2} \mathrm{O}_{3}(\mathrm{CI})$ & 9.1 & 0.24 & 15 & 2.4 & 20.0 & 4.9 \\
\hline
\end{tabular}

${ }^{\mathrm{a}} \mathrm{H}_{2}$ consumption below $773 \mathrm{~K}$ in TPR profiles.

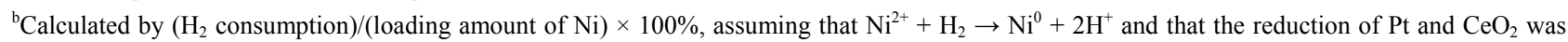
neglected.

${ }^{\mathrm{c}} \mathrm{H}_{2}$ adsorption is total adsorption at room temperature, and $\mathrm{H} / \mathrm{Ni}=1$ is assumed. The adsorption of $\mathrm{H}_{2}$ on $\mathrm{Pt}$ was neglected because of the small molar ratio of Pt to Ni.

${ }^{\mathrm{d}}$ Dispersion calculated by $2 \times\left(\mathrm{H}_{2}\right.$ adsorption $) /($ loading amount of $\mathrm{Ni}) /($ reduction degree $) \times 100 \%[45,46]$.

${ }^{\mathrm{e}}$ Particle size of Ni metal calculated by the relation: particle size $(\mathrm{nm})=9.71 /$ dispersion $(\%) \times 10[45,46]$. 
the temperature range of the $\mathrm{H}_{2}$ consumption was much broader. The TPR profile of $\mathrm{Pt}(0.1) / \mathrm{Ni}(12) / \mathrm{MgO}(2) / \mathrm{Al}_{2} \mathrm{O}_{3}$ was also obtained, and the main peak was located at about $1073 \mathrm{~K}$. As shown in Fig. 2, the $\mathrm{NiO}$ on $\alpha-\mathrm{Al}_{2} \mathrm{O}_{3}$ can be reduced below $873 \mathrm{~K}$. Based on these results, it is interpreted that the presence of $\mathrm{MgO}$ decreases the reducibility of $\mathrm{Ni}$ species and it can be caused by the strong interaction between $\mathrm{NiO}$ and $\mathrm{MgO}$ obtained by the formation of $\mathrm{NiO}-\mathrm{MgO}$ solid solution. The molar ratio of $\mathrm{MgO}$ to $\mathrm{NiO}$ is only $1 / 4$, but the effect of $\mathrm{MgO}$ is rather strong. The Ni-based reduction degree on $\mathrm{Pt}(0.1) / \mathrm{Ni}(12) / \mathrm{CeO}_{2}(15) /$ $\mathrm{Al}_{2} \mathrm{O}_{3}$ below $773 \mathrm{~K}$ decreased significantly to about $1 / 3$ by the addition of $\mathrm{MgO}$. This tendency was more remarkable on $\mathrm{Pt}(0.1) / \mathrm{Ni}(12) / \mathrm{MgO}(2) / \mathrm{Al}_{2} \mathrm{O}_{3}$. In addition, the amount of $\mathrm{H}_{2}$ adsorption on fresh catalysts is also listed in Table 5. The amount of $\mathrm{H}_{2}$ adsorption on $\mathrm{Pt}(0.1) / \mathrm{Ni}(12) / \mathrm{CeO}_{2}(15) /$ $\mathrm{MgO}(2) / \mathrm{Al}_{2} \mathrm{O}_{3}$ was almost the same as that on $\mathrm{Pt}(0.1) /$ $\mathrm{Ni}(12) / \mathrm{CeO}_{2}(15) / \mathrm{Al}_{2} \mathrm{O}_{3}$, although the reduction degree was much lower. This behavior indicates that the $\mathrm{MgO}$ addition promotes the dispersion of $\mathrm{Ni}$ metal particles, although it decreases the reduction degree of $\mathrm{Ni}$ species. The negative effect can be compensated by the promoting effect. The amount of $\mathrm{H}_{2}$ adsorption on $\mathrm{Pt}(0.1) / \mathrm{Ni}(12) / \mathrm{MgO}(2) / \mathrm{Al}_{2} \mathrm{O}_{3}$ was much smaller than those on other catalysts, and this can be connected to lower catalytic performance in the steam reforming of tar (Fig. 9). Furthermore, the TPR profile of $\mathrm{Pt}(0.1) / \mathrm{Ni}(12) / \mathrm{CeO}_{2}(15) / \mathrm{MgO}(2) / \mathrm{Al}_{2} \mathrm{O}_{3}$ is also related to the performance of catalysts without $\mathrm{H}_{2}$ reduction (Fig. 10). The slower activation process by the tar over $\mathrm{Pt}(0.1) / \mathrm{Ni}(12) /$ $\mathrm{CeO}_{2}(15) / \mathrm{MgO}(2) / \mathrm{Al}_{2} \mathrm{O}_{3}$ is explained by the lower reducibility.

Figure 12 shows the catalytic performance with time on stream at $923 \mathrm{~K}$ over the $\mathrm{Pt}(0.1) / \mathrm{Ni}(12) / \mathrm{CeO}_{2}(15) / \mathrm{Al}_{2} \mathrm{O}_{3}$ and $\mathrm{Pt}(0.1) / \mathrm{Ni}(12) / \mathrm{CeO}_{2}(15) / \mathrm{MgO}(2) / \mathrm{Al}_{2} \mathrm{O}_{3}$ catalysts. The formation rate and $\mathrm{C}$-conversion on the $\mathrm{Pt}(0.1) / \mathrm{Ni}(12) /$ $\mathrm{CeO}_{2}(15) / \mathrm{Al}_{2} \mathrm{O}_{3}$ catalyst decreased drastically at about 120 $\mathrm{min}$, and this behavior corresponded to catalyst deactivation [31]. On the other hand, the $\mathrm{Pt}(0.1) / \mathrm{Ni}(12) / \mathrm{CeO}_{2}(15) /$ $\mathrm{MgO}(2) / \mathrm{Al}_{2} \mathrm{O}_{3}$ catalyst maintained high activity even after $240 \mathrm{~min}$. This indicated that the addition of $\mathrm{MgO}$ can improve the catalyst stability.

The dispersion of the $\mathrm{Pt}(0.1) / \mathrm{Ni}(12) / \mathrm{CeO}_{2}(15) / \mathrm{MgO}(2) /$ $\mathrm{Al}_{2} \mathrm{O}_{3}$ is higher than that of $\mathrm{Pt}(0.1) / \mathrm{Ni}(12) / \mathrm{CeO}_{2}(15) / \mathrm{Al}_{2} \mathrm{O}_{3}$ (Table 5) and $\mathrm{MgO}$ addition enhanced the $\mathrm{Ni}$ dispersion caused by strong interaction between $\mathrm{Ni}$ and $\mathrm{MgO}$. Figure 13 shows the XRD patterns of $\mathrm{Pt}(0.1) / \mathrm{Ni}(12) / \mathrm{CeO}_{2}(15) /$ $\mathrm{Al}_{2} \mathrm{O}_{3}$ and $\mathrm{Pt}(0.1) / \mathrm{Ni}(12) / \mathrm{CeO}_{2}(15) / \mathrm{MgO}(2) / \mathrm{Al}_{2} \mathrm{O}_{3}$ after reduction, reaction, and regeneration. The average particle size of $\mathrm{Ni}$ metal on $\mathrm{Pt}(0.1) / \mathrm{Ni}(12) / \mathrm{CeO}_{2}(15) / \mathrm{Al}_{2} \mathrm{O}_{3}$ after the reduction was estimated to be $18.7 \mathrm{~nm}$. The reaction and the regeneration increased the particle size of $25.1 \mathrm{~nm}$ and 30.5 $\mathrm{nm}$, respectively. This behavior indicates that the Ni metal
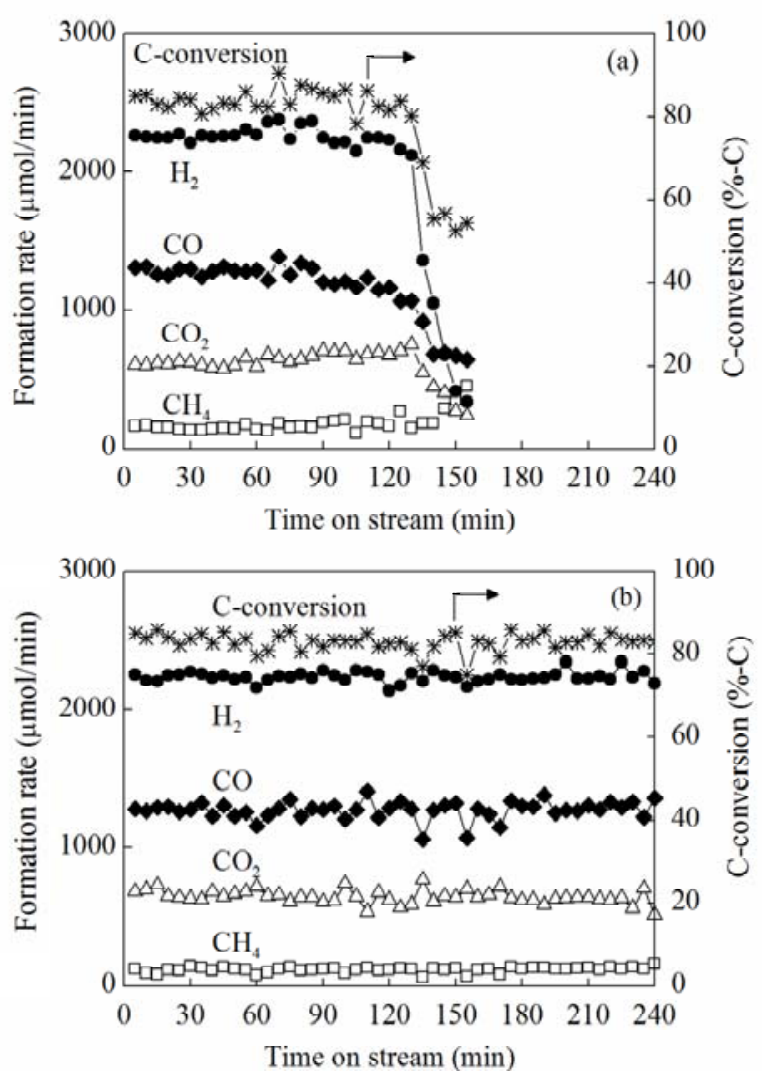

Fig. 12. Catalytic performance in steam reforming of tar with time on stream over (a) $\mathrm{Pt}(0.1) / \mathrm{Ni}(12) / \mathrm{CeO}_{2}(15) / \mathrm{Al}_{2} \mathrm{O}_{3}$ (CI) and (b) $\mathrm{Pt}(0.1) / \mathrm{Ni}(12) / \mathrm{CeO}_{2}(15) / \mathrm{MgO}(2) / \mathrm{Al}_{2} \mathrm{O}_{3}$ (CI) [31]. Conditions: biomass, $60 \mathrm{mg} / \mathrm{min}\left(\mathrm{H}_{2} \mathrm{O}, 9.2 \%\right.$; C, $2191 \mu \mathrm{mol} / \mathrm{min}$; H, $3543 \mu \mathrm{mol} / \mathrm{min}$; $\mathrm{O}, 1475 \mu \mathrm{mol} / \mathrm{min}$ ); steam, $1110 \mu \mathrm{mol} / \mathrm{min}$, (added $\left.\mathrm{H}_{2} \mathrm{O}\right) / \mathrm{C}=0.5$; reaction temperature, $923 \mathrm{~K}$; catalyst, $1.0 \mathrm{~g}$; $\mathrm{H}_{2}$ reduction at $773 \mathrm{~K}$ for $30 \mathrm{~min}$.

particles are aggregated gradually in each treatment step. It is characteristic that the peak assigned to $\mathrm{Ni}$ metal on $\mathrm{Pt}(0.1) / \mathrm{Ni}(12) / \mathrm{CeO}_{2}(15) / \mathrm{MgO}(2) / \mathrm{Al}_{2} \mathrm{O}_{3}$ after the reduction was much smaller than that on $\mathrm{Pt}(0.1) / \mathrm{Ni}(12) /$ $\mathrm{CeO}_{2}(15) / \mathrm{Al}_{2} \mathrm{O}_{3}$. This suggests that much smaller Ni metal particles are majorly present on the catalyst surface. The peak grew after the reaction, and the Ni metal particles aggregated to some extent. But the regeneration reproduced the very small, broad XRD peak, suggesting the re-dispersion of the aggregated particles.

\section{Steam reforming of tar over $\mathrm{Ni} / \mathrm{MnO} / \mathrm{Al}_{2} \mathrm{O}_{3}$} [32]

From the above results, it is concluded that the interaction of $\mathrm{Ni}$ and $\mathrm{CeO}_{2}$ promoted the steam reforming of tar, especially by the activation of tar on Ni metal surface and the supply of oxygen atoms from the redox property of $\mathrm{CeO}_{2}$. Here, we attempted the replacement of $\mathrm{CeO}_{2}$ with other redox species such as $\mathrm{Mn}$ oxides. $\mathrm{Ni} / \mathrm{MnO}_{x} / \mathrm{Al}_{2} \mathrm{O}_{3}(\mathrm{CI})$ was 

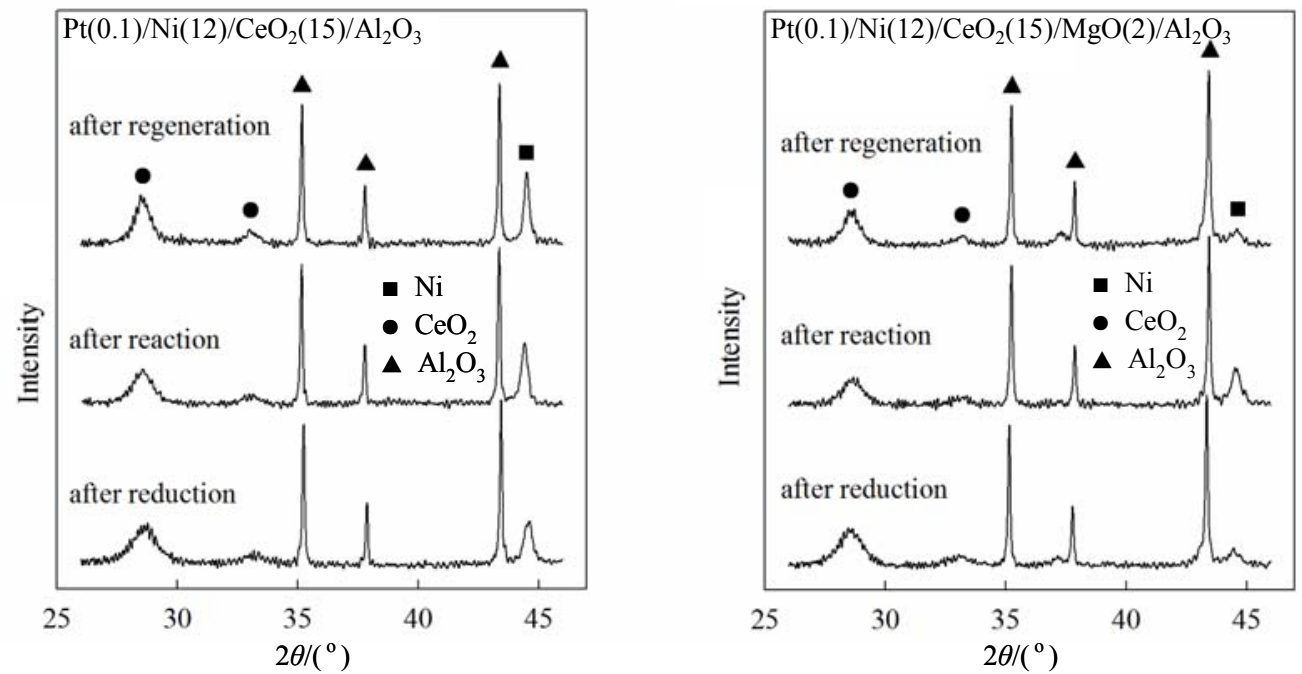

Fig. 13. $\mathrm{XRD}$ patterns of $\mathrm{Pt}(0.1) / \mathrm{Ni}(12) / \mathrm{CeO}_{2}(15) / \mathrm{Al}_{2} \mathrm{O}_{3}$ and $\mathrm{Pt}(0.1) / \mathrm{Ni}(12) / \mathrm{CeO}_{2}(15) / \mathrm{MgO}(2) / \mathrm{Al}_{2} \mathrm{O}_{3}$ after reduction, reaction (Fig. 12), and regeneration (calcination at $873 \mathrm{~K}$ and reduction at $773 \mathrm{~K}$ ) [31].

prepared by the co-impregnation method using the mixed aqueous solution of $\mathrm{Ni}\left(\mathrm{NO}_{3}\right)_{2} \cdot 6 \mathrm{H}_{2} \mathrm{O}$ and $\mathrm{Mn}\left(\mathrm{NO}_{3}\right)_{2} \cdot 6 \mathrm{H}_{2} \mathrm{O}$ in a similar way to that of $\mathrm{Ni} / \mathrm{CeO}_{2} / \mathrm{Al}_{2} \mathrm{O}_{3}(\mathrm{CI})$ [32]. The loading amounts of $\mathrm{Ni}$ and $\mathrm{MnO}$ are described in parentheses as mass percent on the catalyst.

Figure 14 compares the catalytic performance in steam reforming of tar over $\mathrm{Ni}(12) / \mathrm{MnO}(20) / \mathrm{Al}_{2} \mathrm{O}_{3}$ and $\mathrm{Ni}(12) /$ $\mathrm{CeO}_{2}(15) / \mathrm{Al}_{2} \mathrm{O}_{3}$ catalysts. The activity of $\mathrm{Ni}(12) / \mathrm{MnO}(20) /$ $\mathrm{Al}_{2} \mathrm{O}_{3}$ was so high that the tar was almost completely converted at all reaction temperatures. On the other hand, the activity of $\mathrm{Ni}(12) / \mathrm{CeO}_{2}(15) / \mathrm{Al}_{2} \mathrm{O}_{3}$ was not so high as that of $\mathrm{Ni}(12) / \mathrm{MnO} /(20) / \mathrm{Al}_{2} \mathrm{O}_{3}$, and the residual tar was detected at

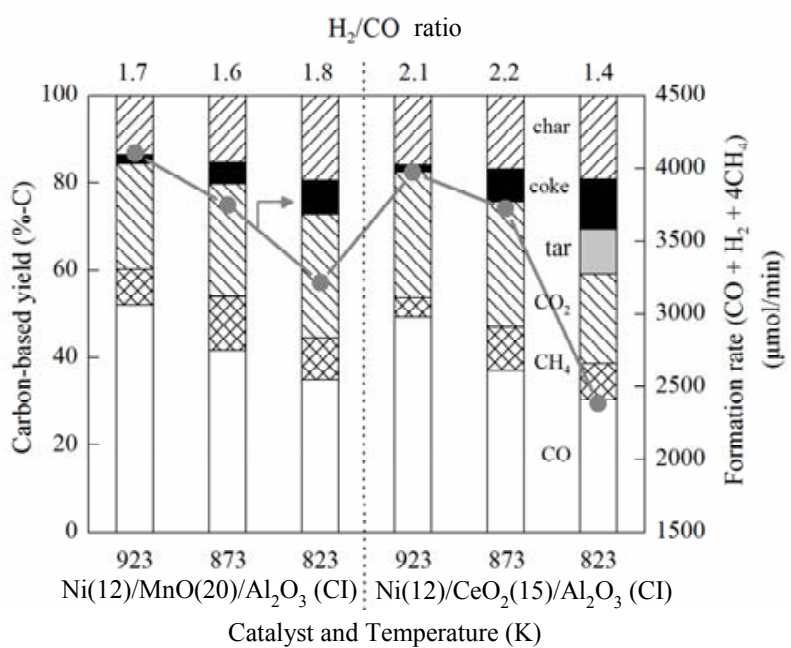

Fig. 14. Comparison of catalytic performance in steam reforming of tar over $\mathrm{Ni}(12) / \mathrm{MnO}(20) / \mathrm{Al}_{2} \mathrm{O}_{3}(\mathrm{CI})$ and $\mathrm{Ni}(12) / \mathrm{CeO}_{2}(15) / \mathrm{Al}_{2} \mathrm{O}_{3}(\mathrm{CI})$ [32]. Conditions: biomass, $60 \mathrm{mg} / \mathrm{min}\left(\mathrm{H}_{2} \mathrm{O}, 9.2 \%\right.$; $\mathrm{C}, 2191 \mu \mathrm{mol} / \mathrm{min}$; $\mathrm{H}, 3543 \mu \mathrm{mol} / \mathrm{min}$; O, $1475 \mu \mathrm{mol} / \mathrm{min}$ ); steam, $1110 \mu \mathrm{mol} / \mathrm{min}$, (added $\left.\mathrm{H}_{2} \mathrm{O}\right) / \mathrm{C}=0.5$; catalyst, $0.5 \mathrm{~g} ; \mathrm{H}_{2}$ reduction, $773 \mathrm{~K}, 30 \mathrm{~min}$. Loading amount: $\mathrm{Ni}, 12 \mathrm{wt} \% ; \mathrm{MnO}_{2}, 20 \mathrm{wt} \% ; \mathrm{CeO}_{2}, 15 \mathrm{wt} \%$.
$823 \mathrm{~K}$, although almost no tar was observed above $873 \mathrm{~K}$. In addition, at each reaction temperature, the order of the resistance to coke formation was $\mathrm{Ni}(12) / \mathrm{MnO}(20) / \mathrm{Al}_{2} \mathrm{O}_{3}>$ $\mathrm{Ni}(12) / \mathrm{CeO}_{2}(15) / \mathrm{Al}_{2} \mathrm{O}_{3}$. These results indicate that the additive effect of $\mathrm{MnO}$ was more significant than that of $\mathrm{CeO}_{2}$. The promoting effect of $\mathrm{MnO}_{x}$ addition can be explained in a similar way as that of $\mathrm{CeO}_{2}$ addition, that is, the oxygen atoms derived from $\mathrm{MnO}_{x}$ species can be supplied to the $\mathrm{Ni}$ species to promote the reaction between carbonaceous species on Ni and oxygen species [32].

\section{Conclusions}

The Ni catalyst supported on $\mathrm{CeO}_{2}$ was effective to the suppression of coke deposition in the steam reforming of tar, and this property can be related to the $\mathrm{Ni}$ on $\mathrm{CeO}_{2}$ with high reducibility. The addition of $\mathrm{CeO}_{2}$ to $\mathrm{Ni} / \mathrm{Al}_{2} \mathrm{O}_{3}$ by the co-impregnation method led to strong interaction between $\mathrm{Ni}$ metal and $\mathrm{CeO}_{2}$ by the formation of $\mathrm{Ni}-\mathrm{CeO}_{2}$ nanocomposite structure. This $\mathrm{Ni} / \mathrm{CeO}_{2} / \mathrm{Al}_{2} \mathrm{O}_{3}$ catalyst showed high activity and resistance to coke deposition in the steam reforming of tar. The addition of a small amount of $\mathrm{Pt}$ to $\mathrm{Ni} / \mathrm{CeO}_{2} / \mathrm{Al}_{2} \mathrm{O}_{3}$ promoted the catalyst reducibility, and the catalyst was reduced with tar and steam easily. Further addition of $\mathrm{MgO}$ to $\mathrm{Pt} / \mathrm{Ni} / \mathrm{CeO}_{2} / \mathrm{Al}_{2} \mathrm{O}_{3}$ enabled the re-dispersion of the aggregated $\mathrm{Ni}$ particles via $\mathrm{NiO}-\mathrm{MgO}$ solid solution formation and its reduction. High performance of $\mathrm{Ni}-\mathrm{CeO}_{2}$ by the redox property of $\mathrm{CeO}_{2}$ suggests the potential of other oxides such as manganese oxides. It is found that manganese oxides are also an effective additive on the $\mathrm{Ni}$ catalysts for the steam reforming of tar. In the development of the catalysts for the steam reforming of tar, the optimization of the additives and their composition is important, and 
this can give various functions including high activity, stability, self-activation, and self-regeneration properties to catalysts.

\section{References}

1 Mckendry P. Bioresour Technol, 2002, 83: 55

2 Huber G W, Iborra S, Corma A. Chem Rev, 2006, 106: 4044

3 Wang L J, Weller C L, Jones D D, Hanna M A. Biomass Bioenerg, 2008, 32: 573

4 de Lasa H, Salaices E, Mazumder J, Lucky R. Chem Rev, 2011, 111: 5404

5 Baker E G, Mudge L K, Brown M D. Ind Eng Chem Res, 1987, 26: 1335

6 Aznar M P, Corella J, Delgado J, Lahoz J. Ind Eng Chem Res, 1993, 32: 1

7 Aznar M P, Caballero M A, Gil J, Martín J A, Corella J. Ind Eng Chem Res, 1998, 37: 2668

8 Marquevich M, Czernik S, Chornet E, Montané D. Energy Fuels, 1999, 13: 1160

9 Czernik S, French R, Feik C, Chornet E. Ind Eng Chem Res, 2002, 41: 4209

10 Bangala D N, Abatzoglou N, Martin J P, Chornet E. Ind Eng Chem Res, 1997, 36: 4184

11 Li J F, Liu J J, Liao S Y, Yan R. Int J Hydrogen Energy, 2010, 35: 7399

12 Li J F, Xiao B, Yan R, Xu X R. Bioresour Technol, 2009, 100: 5295

13 Wang T J, Chang J, Cui X Q, Zhang Q, Fu Y. Fuel Process Technol, 2006, 87: 421

14 Le D D, Xiao X B, Morishita K, Takarada T. J Chem Eng Jpn, 2009, 42: 51

15 Xiao X B, Meng X L, Le D D, Takarada T. Bioresour Technol, 2011, 102: 1975

16 Wang D, Yuan W Q, Ji W. Appl Energy, 2011, 88: 1656

17 Corujo A, Yermán L, Arizaga B, Brusoni M, Castiglioni J. Biomass Bioenerg, 2010, 34: 1695

18 Asadullah M, Ito S-I, Kunimori K, Yamada M, Tomishige K. J Catal, 2002, 208: 255

19 Asadullah M, Miyazawa T, Ito S-I, Kunimori K, Yamada M, Tomishige K. Appl Catal A, 2003, 255: 169

20 Asadullah M, Miyazawa T, Ito S-I, Kunimori K, Yamada M, Tomishige K. Appl Catal A, 2004, 267: 95

21 Asadullah M, Fujimoto K, Tomishige K. Ind Eng Chem Res, 2001, 40: 5894

22 Asadullah M, Ito S-I, Kunimori K, Yamada M, Tomishige K. Environ Sci Technol, 2002, 36: 4476

23 Asadullah M, Miyazawa T, Ito S-I, Kunimori K, Tomishige K. Appl Catal A, 2003, 246: 103

24 Tomishige K, Asadullah M, Kunimori K. Catal Today, 2004, 89: 389

25 Asadullah M, Miyazawa T, Ito S-I, Kunimori K, Koyama S, Tomishige K. Biomass Bioenerg, 2004, 26: 269

26 Miyazawa T, Kimura T, Nishikawa J, Kado S, Kunimori K, Tomishige K. Catal Today, 2006, 115: 254
27 Tomishige K, Kimura T, Nishikawa J, Miyazawa T, Kunimori K. Catal Commun, 2007, 8: 1074

28 Kimura T, Miyazawa T, Nishikawa J, Kado S, Okumura K, Miyao T, Naito S, Kunimori K, Tomishige K. Appl Catal B, 2006, 68: 160

29 Nishikawa J, Miyazawa T, Nakamura K, Asadullah M, Kunimori K, Tomishige K. Catal Commun, 2008, 9: 195

30 Nishikawa J, Nakamura K, Asadullah M, Miyazawa T, Kunimori K, Tomishige K. Catal Today, 2008, 131: 146

31 Nakamura K, Miyazawa T, Sakurai T, Miyao T, Naito S, Begum N, Kunimori K, Tomishige K. Appl Catal B, 2009, 86: 36

32 Koike M, Ishikawa C, Li D L, Wang L, Nakagawa Y, Tomishige K. Fuel, in press, doi: 10.1016/j.fuel.2012.01.073

33 Wang L, Li D L, Koike M, Koso S, Nakagawa Y, Xu Y, Tomishige K. Appl Catal A, 2011, 392: 248

34 Li D L, Wang L, Koike M, Nakagawa Y, Tomishige K. Appl Catal B, 2011, 102: 528

35 Tanaka H, Kaino R, Okumura K, Kizuka T, Nakagawa Y, Tomishige K. Appl Catal A, 2010, 378: 175

36 Tanaka H, Kaino R, Nakagawa Y, Tomishige K. Appl Catal A, 2010, 378: 187

37 Naito S, Tanaka H, Kado S, Miyao T, Naito S, Okumura K, Kunimori K, Tomishige K. J Catal, 2008, 259: 138

38 Koso S, Furikado I, Shimao A, Miyazawa T, Kunimori K, Tomishige K. Chem Commun, 2009: 2035

39 Koso S, Ueda N, Shinmi Y, Okumura K, Kizuka T, Tomishige K. J Catal, 2009, 267: 89

40 Shinmi Y, Koso S, Kubota T, Nakagawa Y, Tomishige K. Appl Catal B, 2010, 94: 318

41 Chen K Y, Koso S, Kubota T, Nakagawa Y, Tomishige K. ChemCatChem, 2010, 2: 547

42 Amada Y, Koso S, Nakagawa Y, Tomishige K. ChemSusChem, 2010, 3: 728

43 Ishida Y, Ebashi T, Ito S-I, Kubota T, Kunimori K, Tomishige K. Chem Commun, 2009: 5308

44 Ebashi T, Ishida Y, Nakagawa Y, Ito S-I, Kubota T, Tomishige K. J Phy Chem C, 2010, 114: 6518

45 Bartholomew C H, Pannell R B, Butler J L. J Catal, 1980, 65: 335

46 Arena F, Horrell B A, Cocke D L, Parmaliana A, Giordano N. J Catal, 1991, 132: 58

47 Yamazaki O, Tomishige K, Fujimoto K. Appl Catal A, 1996, 136: 49

48 Tomishige K, Chen Y G, Fujimoto K. J Catal, 1999, 181: 91

49 Nurunnabi M, Mukainakano Y, Kado S, Li B T, Kunimori K, Suzuki K, Fujimoto K, Tomishige K. Appl Catal A, 2006, 299: 145

50 Miyazawa T, Okumura K, Kunimori K, Tomishige K. J Phys Chem C, 2008, 112: 2574

51 Chen Y G, Tomishige K, Yokoyama K, Fujimoto K. Appl Catal A, 1997, 165: 335

52 Li D L, Nakagawa Y, Tomishige K. Appl Catal A, 2011, 408: 1

53 Li B T, Kado S, Mukainakano Y, Miyazawa T, Miyao T, Naito S, Okumura K, Kunimori K, Tomishige K. J Catal, 2007, 245: 
144

54 Tomishige K, Kanazawa S, Sato M, Ikushima K, Kunimori K. Catal Lett, 2002, 84: 69

55 Li B T, Kado S, Mukainakano Y, Nurunnabi M, Miyao T, Naito S, Kunimori K, Tomishige K. Appl Catal A, 2006, 304: 62

56 Mukainakano Y, Li B T, Kado S, Miyazawa T, Okumura K, Miyao T, Naito S, Kunimori K, Tomishige K. Appl Catal A, 2007, 318: 252

57 Miyata T, Li D L, Shiraga M, Shishido T, Oumi Y, Sano T, Takehira K. Appl Catal A, 2006, 310: 97

58 Li D L, Atake I, Shishido T, Oumi Y, Sano T, Takehira K. J
Catal, 2007, 250: 299

59 Li D L, Shishido T, Oumi Y, Sano T, Takehira K. Appl Catal A, 2007, 332: 98

60 Li D L, Nishida K, Zhan Y Y, Shishido T, Oumi Y, Sano T, Takehira K. Appl Catal A, 2008, 350: 225

61 Nurunnabi M, Li B T, Kunimori K, Suzuki K, Fujimoto K-I, Tomishige K. Catal Lett, 2005, 103: 277

62 Nurunnabi M, Li B T, Kunimori K, Suzuki K, Fujimoto K-I, Tomishige K. Appl Catal A, 2005, 292: 272

63 Nurunnabi M, Mukainakano Y, Kado S, Miyazawa T, Okumura K, Miyao T, Naito S, Suzuki K, Fujimoto K-I, Kunimori K, Tomishige K. Appl Catal A, 2006, 308: 1 